Article

\title{
Chronotype, Risk and Time Preferences, and Financial Behaviour
}

\author{
Di Wang *(D), Frank McGroarty $(\mathbb{D})$ and Eng-Tuck Cheah
}

Southampton Business School, University of Southampton, Southampton SO17 1BJ, UK;

f.j.mcgroarty@soton.ac.uk (F.M.); jeremy.cheah@soton.ac.uk (E.-T.C.)

* Correspondence: dwangsoton2014@gmail.com; Tel.: +44-742-241-3613

Received: 14 September 2018; Accepted: 8 October 2018; Published: 10 October 2018

\begin{abstract}
This paper examines the effect of chronotype on the delinquent credit card payments and stock market participation through preference channels. Using an online survey of 455 individuals who have been working for 3 to 8 years in companies in mainland China, the results reveal that morningness is negatively associated with delinquent credit card payments. Morningness also indirectly predicts delinquent credit card payments through time preference, but this relationship only exists when individuals' monthly income is at a low and average level. On the other hand, financial risk preference accounts for the effect of morningness on stock market participation. Consequently, an additional finding is that morningness is positively associated with financial risk preference, which contradicts previous findings in the literature. Finally, based on the empirical evidence, we discuss the plausible mechanisms that may drive these relationships and the implications for theory and practice. The current study contributes to the literature by examining the links between circadian typology and particular financial behaviour of experienced workers.
\end{abstract}

Keywords: chronotype; risk preference; time preference; credit debt; stock market participation

\section{Introduction}

Circadian rhythm is a time-based oscillation in physiological and biological functions that reflect a cycle of approximately $24 \mathrm{~h}$. For humans and animals, the inner biological clock, which is situated in the suprachiasmatic nuclei of the hypothalamus, regulates this rhythm [1]. Sequentially, the hypothalamus secretes melatonin [2]. There is board individual heterogeneity in circadian rhythms, which can be identified by biological markers, such as sleep-wake patterns [3], body temperature [4,5], and genes [6]. The sleep-wake cycle can be measured as circadian chronotypes, also known as morningness-eveningness, which are distributed normally on a continuum [7], allowing for the categorization of individuals into three groups: morning chronotype, neither type, and evening chronotype. Morning chronotype individuals, also known as "larks", are more likely to wake up in the early morning and to go asleep in the early evening as well. Evening chronotype individuals, also known as "owls", prefer to go to sleep late in the evening and to wake up later in the day [8].

For the last two decades, there has been increasing interest research into the effect of morningness-eveningness on multiple facets of life. Studies have reported links between the circadian chronotypes and work shifts [9], jet lag [10,11], cognitive efficiency [12], cognitive style [13], personality traits [14], academic performance [1], mental disorders [15,16], and life habits [17]. Based on these findings, we note that the circadian typologies influence psychological perspectives and behaviour, but mainly in the aspects of work, education, and health. Very few researchers have examined the association between morningness-eveningness and financial behaviour. The effect of the circadian rhythm on financial well-being is important because financial well-being contributes positively to general life satisfaction [18]. 
The first goal of this study is to investigate whether the circadian typology influence financial behaviour, especially delinquent credit card payments and stock market participation. First, revolving credit borrowers who do not entirely pay off their loans after the monthly deadline or miss payments have a larger amount of credit debt, as compared to those who pay off such loan on time. From a financial perspective, delinquent credit card payments are not of benefit to long-term financial health because adopting the habit of making loan payment late leads to accumulated outstanding debt [19]. Such consumers are more likely to have incomplete credit card debts, which in the short run leads to higher interest rates, financial penalties, and higher outstanding balances [20]. Investigating the effect of morningness-eveningness on delinquent credit card payments could provide practical implications, such as interventions that prevent this behaviour or that help to break the habit of not paying back loans according to monthly time schedule. Second, participation in the stock market is essentially a financial decision [21], and it might be financially harmful if one refuses to take part in the stock market over the long term. The reason is that equity premium can provide long-term benefits for personal savings, which in turn influence personal financial well-being.

The second goal of the present study is to investigate the possible mechanisms through which morningness-eveningness influences delinquent credit card payments and stock market participation. We draw on the theories of risk preference and time preference, in order to provide a richer explanation regarding the likely channels. The first reason is that morning-types are positively associated with future time preference [22,23], while Meier and Sprenger [24] reported that present-biased individuals tend to have higher revolving credit balances as compared with future-oriented individuals. Hence, the time perspective appears to be a possible channel between the circadian typology and incomplete monthly credit debt payments. The second reason is that morning larks are negatively associated with risk attitudes [25], while risk preference is a predictor of the probability of participating in the stock market [26]. Therefore, we anticipate risk preference would be a possible channel between chronotypes and owning equity. In addition, income may moderate the indirect effects of the circadian typologies on the likelihood of delinquent credit card payments and investments in stock because income is a determinant of outstanding balances among credit card revolvers $[19,27]$ and is associated with risk preference [28].

We launched an online survey and received 455 valid questionnaires from employees who have three to eight years of working experience. We used the Composite Scale of Morningness (CSM) [29] to measure the circadian chronotypes, measured the time perspective by following Finke and Huston [30], and drew on a single question to measure financial risk preference, as proposed by Dohmen et al. [26]. We used regression and path analysis to examine the hypothesized relationships and the results revealed significant findings. First, the results indicate that morningness inhibits the likelihood of conducting late payments or missing payments on credit card debt. Second, time preference partially mediates the relationship between the morning chronotype and delinquent credit card payment, but this indirect effect only exists when subjects' income level is at average and low levels, for the path from time preference to incomplete credit card payment. The present study is of help to put forward the underlying mechanism and the conditions of the association between the circadian typology and delinquent credit card payment. Furthermore, another novel finding is that financial risk preference fully mediates the link between morningness and the probability of owning equity. Hence, the current study helps to elucidate the unique channel and mechanism through which morning type exert influence on stock market participation. Furthermore, as those characteristics have been found in experienced workers, the results could be a valuable tool for financial professionals who should consider circadian rhythms when developing and introducing financial products or financial services for the morning-type, intermediate-type, and evening-type population. Future research could enhance the study of the relationship between morningness-eveningness, preference constructs and financial behaviour by using a wider population, such as adding an aging group, sampling from different countries. In addition, longitudinal studies would be particularly powerful for testing the proposed relationships. 
We organize the present paper as follows: In Section 4.2, we given a literature review to build up the hypothesized frameworks to examine the relationship between circadian chronotypes, risk and time preference, and financial behaviour. In Section 4.3, we describe sampling method, measurements of data, descriptive statistics of data, and econometric models. In Section 4.4, we report the results. Section 4.5 is discussion, which provides theoretical and practical implications, as well as some limitations of our research. We conclude in Section 4.6.

\section{Literature Review}

\subsection{Overview of Theoretical Rationale}

In the context of personality psychology, circadian rhythm varies among individuals who can be classified as morning-types, neither-types, and evening-types. In particular, morning larks wake up in the early morning, achieve their peak performance physically and mentally in the early morning, and go to bed early in the evening. In contrast to morning larks, evening owls prefer to wake up late in the morning and go to bed late in the evening, and their peak performance is later in the day or in the evening [31,32].

Researchers usually elicit circadian chronotypes by using self-reported survey questions [33]. The first and most commonly used measure is the Morningness-eveningness questionnaire (MEQ), as proposed by Horne and Ostberg [8]. Nevertheless, MEQ has been criticized due to its length (19 items) [34]. Its value arranges from 20 to 75. Smith et al. [29] developed a short composite scale with 13 items (CSM). The authors classified the values on their morningness-eveningness scale into three groups using the cut-off points, with morning types (40 and above), intermediate types (23-43), and evening types ( 22 or fewer). More recently, Randler et al. [35] proposed a new measure with 15 items, termed morningness-eveningness-stability-scale, improved (MESSi), and Faßl et al. [36] provided the evidence to validate this scale. We will use the CSM scale for the Chinese population to measure circadian chronotypes and to validate the Chinese version of CSM.

The determinants of circadian typologies are various, including demographics, environmental, and biological and genetic factors [31,32]. First, age is a demographic factor that is positively associated with a morning orientation after the end of adolescence [37,38]. Gender is another demographic factor; males are more likely to be evening owls, while females appear to be more morning-oriented [39]. Second, the photoperiod at birth is an environmental factor that influences circadian chronotypes. Individuals who were born in autumn and winter are prone to be morning-types, whereas those born between spring and autumn are more likely to be evening owls [40]. Another environmental factor is the longitude and latitude of residence. People who live in the East and North are more likely to be morning larks [41]. Third, the biological expression of individual differences in circadian rhythms reflects that the acrophase of melatonin for morning larks occurs in the early morning, as compared to evening owls [42]. Genetic factors also explain the variance in individual circadian rhythms, as a single nucleotide polymorphism positioned at the 3' flanking area of humans' CLOCK gene can be an interpreter of morning orientation for ordinal grownups [43].

Circadian typology has been documented as a key individual characteristic in life, which influences cognitive performance, work performance [44], and psychological well-being [45]. Prior research reported that the cognitive performance of morning-types is lower than that of evening-types [46]. However, evening owls are better at intermediate memory [47]. Circadian typology is also associated with psychiatric disorders, personality traits [14,31], work shifts [48], and life habits $[17,49]$. Therefore, previous studies have explored the effects of circadian rhythms on behaviour in the contexts of education, work, and health. However, to the best of our knowledge, very few studies have examined the effect of circadian rhythms on financial behaviour, such as revolving credit balance and stock market participation.

A credit card is a tool for convenient payment [50]. Credit card holder who do not pay off the entire loan before the monthly deadline or who miss the payments have higher amounts of 
credit card debt when compared with those who pay off in time. Kim and DeVaney [19] highlighted that poor loan payment habits drive the accumulation of outstanding debt. Hence, consumers who have such habits are more likely to have delinquent credit card payment, which in the short-run leads to higher interest rates, financial penalties, and higher outstanding balances [20], and in the long-run, harms consumers' financial well-being. If circadian rhythms can predict the possibility of having delinquent credit card debt, a better understanding of this characteristic may help to improve borrowing behaviour and creditworthiness, which in turn contribute to a better financial situation. For example, if evening-types are positively associated with the possibility of having a revolving credit balance, shifting into morning circadian rhythm could be a helpful intervention, as morning larks are more conscientious and proactive about achieving long-term goals.

Stock market participation is an important financial decision [21]. It can be costly for individuals who do not invest in stocks because the stock premium can be a key predictor of the long-term benefits for personal savings, which in turn determine the status of personal financial well-being. Prior research has proposed a number of external and internal factors, which predict the likelihood to invest in stock, such as social interaction [51], awareness [52], financial literacy [53], IQ [54], health [55,56], gender [21], and access to Internet [57]. Given the evidence that circadian rhythm are driven by biological and genetic factors and that they remain stable over time [1], we examine whether morningness-eveningness influences the willingness to participate in the stock market.

Since these behaviours are financially meaningful, investigating the effect of circadian rhythms on these financial behaviours is our research goal.

\subsection{Conceptual Model and Hypotheses Development}

\subsubsection{Morning Larks and Delinquent Credit Card Payments (H1)}

The first goal of the present paper is to explore the relationship between morning-types and revolving credit card debt. In the literature, Randler [33] reported that morning larks are prone to be more proactive than evening owls, which provides an inspiring starting point. In particular, proactivity is the willingness and capability to alter a situation to make it in one's favour [58], and it can be influential in a wide range of circumstances. For example, a proactive personality connects to job autonomy through self-efficacy [59]; proactive individuals attain more success in careers, earnings [60], and studying performance [61].

Although few studies have examined the role of the circadian chronotypes in revolving credit card debt, by integrating the role of proactivity, it is reasonable to anticipate the negative association. On the one hand, morning-types are more proactive than evening-types, and on the other hand, proactivity describes the extent of which individuals anticipate, and minimize the negative influence of possible future problems, avoiding them completely if possible [62,63]. At the same time, unpaid balances on credit cards represents such a negative potential problem that will increase consumers' interest rates if they do not pay off their monthly balances on time [64]. Therefore, we expect that morning larks are much less likely to be unable to pay off their monthly credit card balance entirely. Accordingly, we propose:

Hypothesis 1. Morning-types are negatively associated with delinquent credit card payments. Specifically, compared to intermediate- and evening-types, morning larks are less likely to have unpaid credit card debt.

\subsubsection{The Mediating Role of Time Preferences (H2)}

To provide a richer explanation for morning chronotype's influence on delinquent credit card payments, we use theories of time perspective (i.e., future-oriented or present-biased). An individual's conception of time helps them to organize each life event in a methodical and anticipated rhythm [65]. According to the neurological explanation, decisions that are expected to result in a future award in the region of the rational prefrontal cortex, whereas decisions that are expected to result in a present 
award occur in the emotional limbic region in the brain [66]. Present-oriented individuals appear to seek immediate gratification at the cost of future utility. In contrast, future-oriented individuals are more likely to delay gratification in order to achieve long-run goals [67].

Prior studies have reported a relationship between circadian rhythms and time perspectives. In particular, morning-types are positively associated with future time preference $[22,23,65]$ and the processing channel is self-control [65], as more self-control results in reasonable decisions to delay gratification and to concentrate on achieving future goals. On the other hand, previous research has also suggested a link between time preference and credit card debt. Meier and Sprenger [24] reported that present-discounting individuals have higher amount of revolving credit balances, as compared with future-oriented individuals. Their results are also robust when changing the method of calculating the time perspective and the sample selection criteria. Therefore, to examine whether time discounting explains the association between morning-types and delinquent credit card payments, we propose:

Hypothesis 2. Time preference mediates the relationship between morning-types and delinquent credit card payments.

2.2.3. The Moderating Role of Monthly Income in a Second-Stage Moderated Mediation Model (H3 and $\mathrm{H} 4)$

We have proposed that morningness influences the likelihood of delinquent credit card payment through time discounting, and we anticipate the strength of this mediating effect to vary according to the level of income in the path from time preference to delinquent credit card payments.

The life-cycle model assumes that consumers will maximize the utility from lifetime consumption [68], and Bryant [69] proposed that borrowing is intended to change future resources into present resources with the purpose of increasing present consumption. Income is one determinant of outstanding credit card balances $[19,27]$. These researchers reported that income is positively associated with the amount of outstanding credit card debt because the purpose of borrowing is to satisfy individuals' consumption demand throughout their lifetime. Therefore, in contrast to high income individuals, low and average income individuals are less likely to hold revolving credit card debt because they might be worried about the amount of such debt, which will add to their financial burden due to compounding interest rates [19]. In addition, low- and average-income people would care about their personal credit over the long term. Therefore, to maintain a good level of personal credit (i.e., changeable utility from future resources into present resources), future-oriented individuals whose income is at low and average levels, are less likely to have delinquent credit card payments when compared with their counterparts. Accordingly, we predict that income moderates the relationship between time perspectives and the probability of delinquent credit card debt and in turn moderates the indirect effect of morning orientation on delinquent credit card payments through the time perspective:

Hypothesis 3. Income moderates the relationship between time preference and delinquent credit card payments.

Hypothesis 4. The indirect effect of morning-types on delinquent credit card payments through the time perspective, is moderated by income, such that the indirect effect exists for those whose income is at low and average levels.

\subsubsection{Morning Larks and Owning Equity (H5)}

The second goal of the present paper is to investigate the relationship between morning-types and the likelihood of owning hold stock. Prior studies have documented the determinants of stock market participation. They include wealth [70], education [71], background income risk [72,73], physical health [55], mental health [56], financial literacy [53], trust [74], and cultural and social interactions [51,75]. More recently, Rao et al. [76] reported that happiness is positively associated with 
investments in stock, whereas Biss and Hasher [77] reported that both younger and older people who are morning larks have higher levels of happiness. Therefore, we propose, as follows:

Hypothesis 5. Morning-types are positively associated with investments in stock. In particular, compared with intermediate- and evening-types, morning larks are more likely to participate in the stock market.

\subsubsection{The Mediating Role of Financial Risk Preference (H6)}

To provide a richer explanation of why morningness influences investments in stock, we use theories of financial risk preferences. On the one hand, previous research reported that morning larks are less likely to engage in financial risk behaviour and are negatively associated with risk attitudes [25]. These researchers argued that self-control is the underling mechanism, as self-control is able to inhabit impulsivity, which contributes to risky behaviour. Morningness-types tend to be less impulsive. Guven and Hoxha [78] supported this argument as well. Accordingly, it is reasonable to expect that morning larks have a lower level of financial risk preference as compared with evening owls. On the other hand, another stream of literature advocated the opposite, such that happiness is positively associated with risk attitude. Anderson and Galinsky [79] documented that optimism increases individuals' risk preferences, as optimistic people' cognitive appraisals engender high certainty and a higher probability of positive outcomes. Depressed-mood people are more risk averse when compared with neutral and positive-mood individuals [80]. Although the prior literature has provided contradictory arguments regarding the relationship between positive moods and risk preference, given the evidence in the literature about the association between the morning chronotype and risk attitude, and that risk preference as a predictor of participation in the stock market [26], we propose the following hypothesis:

Hypothesis 6. Financial risk preference mediates the relationship between morning-types and stock market participation.

2.2.6. The Moderating Role of Monthly Income in a First-Stage Moderated Mediation Model (H7 and H8)

We have proposed that morningness influences the likelihood of investment in stock through financial risk preference, and we anticipate the strength of this mediating effect to vary according the level of income in the path from morningness to financial risk preference. Income is a determinant of individuals' general risk attitude and financial risk attitude [26]. These researchers reported that wealthier people are more willing to take risk. Tanaka et al. [28] also argued that income is associated with risk preference. Therefore, the effect of morningness on financial risk preference is stronger in the group of people who have average- and high-income levels. Accordingly, we propose, as follows:

Hypothesis 7. Income moderates the relationship between morning-types and financial risk preference.

Hypothesis 8. The indirect effect of morning-types on investments in stock through financial risk preference is moderated by income, such that an indirect effect exist for those whose income is at average and high levels.

To summarize, we illustrate the conceptual models in Figures 1 and 2. 


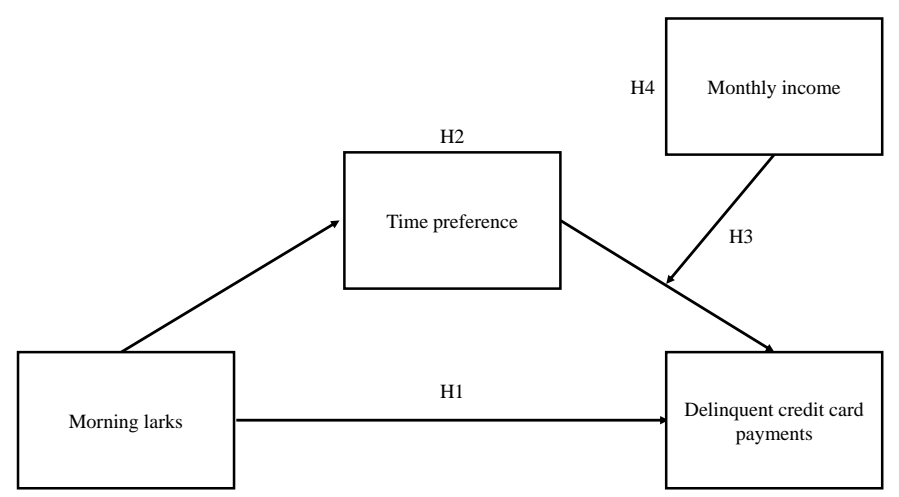

Figure 1. Illustrates the conceptual model for the relationships among morning-types, time preference, and delinquent credit card payments. The direction of the arrows indicates the hypothesized effect.

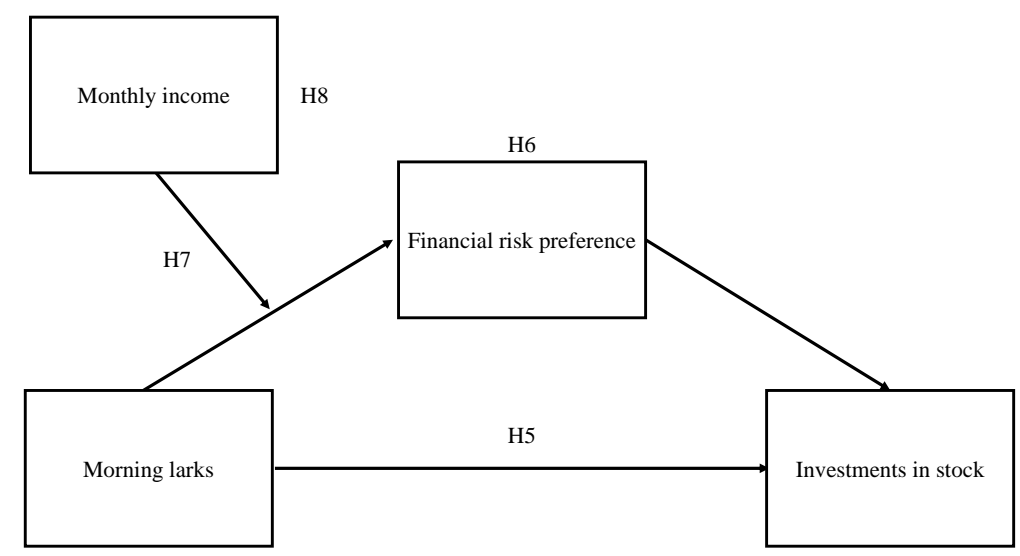

Figure 2. Illustrates the conceptual model for the relationships among morning-types, financial risk preference, and investments in stock. The direction of the arrows indicates the hypothesized effect.

\section{Methods}

\subsection{Sampling and Data Validation}

We gathered the data by using an Internet-mediated survey, which was considered the only financially affordable choice because the target population (experienced labour force in China) is large and geographically scattered [81]. This survey comprises four parts. The first part was a participation information sheet that describes the academic purpose and objective of this research, gave the consent choice to potential respondents, and clarified that the data would remain confidential. The second part included a number of questions regarding circadian rhythms. The third and fourth parts asked for demographic information, individual in risk and time preferences, and specific financial behaviour (i.e., holding stock and having revolving credit card debt).

The present study distributed an online survey on Wjx [82] (previously called Sojump), which is a well-known online panel service provider in China. Online panel data collection is different from traditional online data collection because it collects data from registered online panel registers that agree to respond questionnaires for monetary compensation [83]. Wjx has a large survey-oriented sample pool (more than 2.6 million) in different cities in Mainland China that possesses diverse demographic features. In particular, Wjx selectively invites volunteers and individuals in their registered sampling pool to fill out an online survey, based on its customers' sampling frame. After validation, each respondent is given a monetary award. Hence, our sample should be deemed as a convenient sample [84]. The survey was initially drafted in English and it was subsequently translated to Chinese by the author that is natively speaking Chinese. Afterwards, another native Chinese speaker checked the consistency of the Chinese version survey [85]. 
The Ethics and Research Governance group at the authors' institution approved this study. All of the subjects were given informed consent and they were willing to joining the survey.

Totally, Wjx distributed the survey to 4472 panelists who fit the eligibility criteria in their panel, and 582 full-time employees in China with three to eight years of working experience completed the survey. Because we enabled a force response setting in the survey, there are no missing values. We also enabled attention checks to identify irresponsible participants, which helped to automatically discard 56 questionnaires. Therefore, in fact, we totally collected 526 observations. We further deleted 71 observations because these respondents did not use credit cards, which is one of the interests of the present study, ultimately resulting in 455 observations. Figure 3 is a bar chart that displays the number of respondents from different provinces. Figure 4 illustrates the distribution of respondents on a flat map of China generated in Excel 2016 and provides the population density of China in 2010 [86], in order to detecting whether our sample achieved adequate geographical disperse and representativeness. In general, our online sample roughly fits the geographical distribution of the general population.

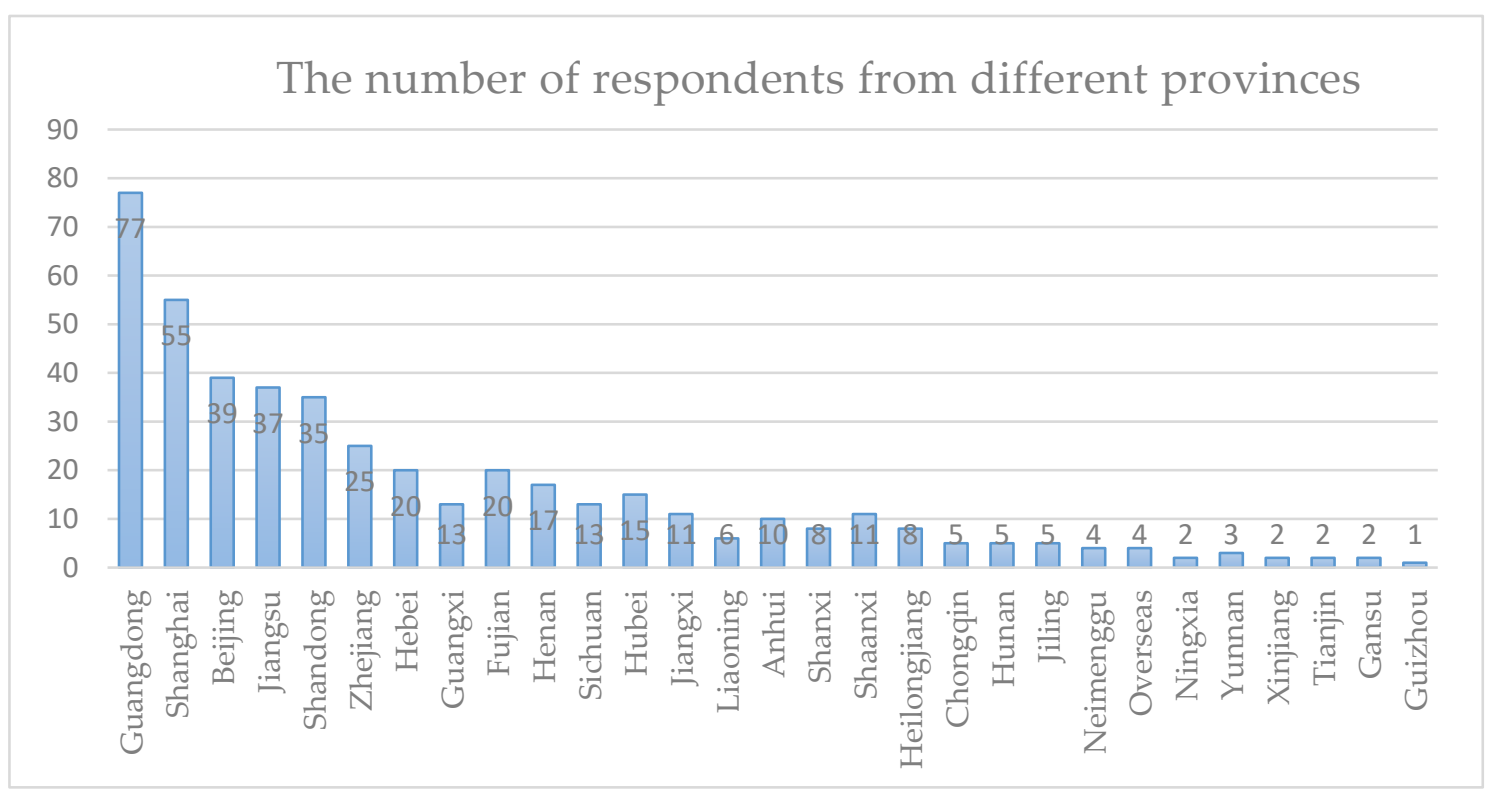

Figure 3. Reports the number of respondents from different provinces in China. Note: This bar chart displays the number of observations by provinces. The $x$-axis lists the names of the provinces, while the $y$-axis lists the number of respondents from each province.

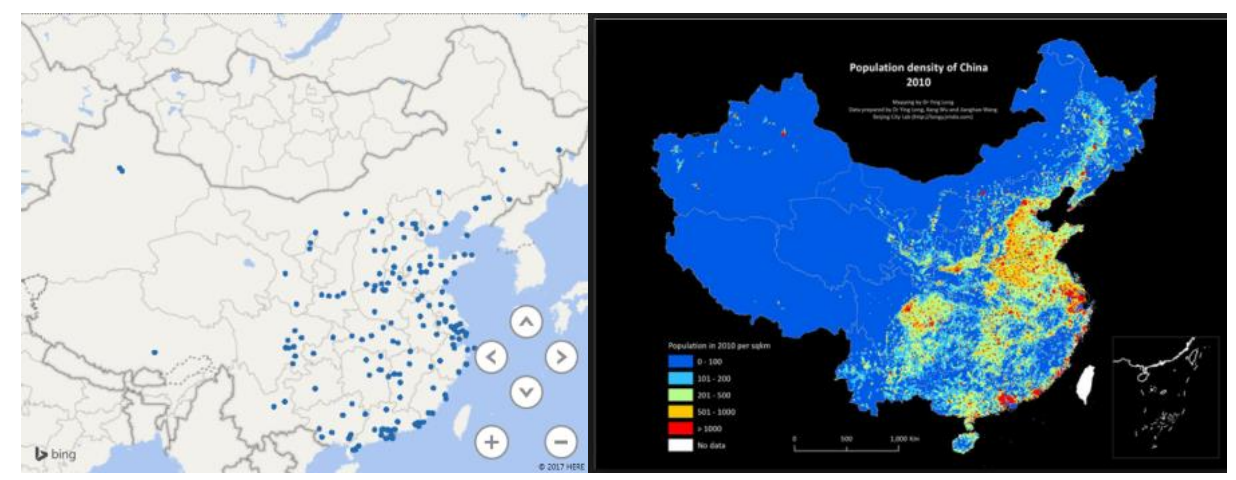

Figure 4. Depicts the locations of the sample participants who live in in China (left) and the population density of China in 2010 (right) [86]. Note: Each solid blue point represents the location of one respondent. From the perspective of geography, our samples are distributed randomly across the provinces of China. 
In addition, we draw the reader's attention to the four observations from overseas. We do not deny the possibility that these respondents had travelled to or temporarily visited overseas countries when they submitted the questionnaires.

Internet-mediated surveys have the advantages of being a cheaper and faster way to collect data and reducing social desirability bias $[87,88]$. However, Couper [89] reported that there are challenges for inferential studies using this mode for surveys, such as non-response bias (i.e., low response rate) and coverage bias (i.e., offline population concerns [90]. The response rate is broadly deemed to be an important sign of data quality [91]. Accordingly, in this paper, the response rate was $13.01 \%(582 / 4472)$, which is low and quite similar to the likely response rate $11 \%$ mentioned by Saunders et al. [92] (p. 421). Therefore, it raised concern about data quality $[89,93]$.

Nevertheless, researchers should evaluate the merits of survey results and not depend solely on the response rate [93], as a low response rate does not necessarily indicate non-response bias, although it raises suspicion. A study with a low response rate that examines relationships should not automatically be assumed to be problematic or less credible [94]. Potential non-response bias derived from a low response rate is less of a concern in a relationship-oriented analysis than in a distributional analysis and non-response bias can indicate discrepancies in survey items [94-96]. In the literature, there is empirical evidence supporting the contention that there is little difference in the results between low-response rate surveys and high-response-rate surveys, such as Smith [96], Visser et al. [97], Curtin et al. [98], Keeter et al. [99]. More recently, Holbrook et al. [100] stated that the low-response survey diminished demographic representativeness, but not that much.

Other concerns with using an online panel survey are coverage bias and self-selection bias. To quantitatively examine these types of bias and determine how our sample might be different from the target population, it is helpful to compare our sample data with the census data regarding Internet penetration, education, age, and gender. First, the Chinese population as of 2017 is 1.4 billion [101], of which approximately one billion can access Internet [102]. Therefore, Internet penetration in China now is approximately $71.4 \%$. In other words, approximately $28.6 \%$ of the population are non-Internet user and are therefore not covered in the sample. Hence, the results would be possibly biased, as the findings might only represent $71.4 \%$ of the entire population. In addition, regarding the education level of the labour force, the median educational attainment in our sample is the undergraduate level, which is higher than shown in census data, as only $36.5 \%$ of the general population have experienced tertiary education [103]. This is a disadvantage of an Internet-mediated survey, which tends to generate a sample with higher educational attainment than the census data [104]. Therefore, we remain cautious and acknowledge these limitations of using an online panel survey in this paper. Nevertheless, age, income and the gender ratio of our sample quite closely match the labour force population in China. First, the proportion of working females in our sample is $62 \%$, and one study reported that $56.7 \%$ of the workforce in China is female [105]. Second, as of 2017, China's average per capita income was 8480 US dollars (equivalent to 56,114 Yuan) [106], which is quite close to the median category of monthly income in our sample of between 5000 and 7500 US dollars (equivalent to annual income 60,000 and 90,000 Yuan). Third, the average age of the labour force in China is 36 years old [107], which is within the median group of our sample of between 30 and 44 years old.

\subsection{Measures}

Chronotype. The composite scale [29] (CSM) extracts 13 items from the Horne and Ostberg [8] scale and the Torsvall and Akerstedt [34] scale. It is widely used to measure morningness-eveningness and has multiple language versions, including French [108], Spanish [109], German [110], and Thai [111]. Specifically, nine items from Hornes and Osberg [8] have Chinese versions in the literature [112,113]; and thus, we directly used these items in the questionnaire. However, four items are from the Torsvall and Akerstedt [34] scale (their items 1, 4, 6, and 7), which have not been translated into Chinese in the literature. Therefore, we invited a Chinese native speaker who is proficient in both English and Chinese to translate these four items in parallel to ensure the validity 
and conceptual correspondence for the Chinese circumstance. The CSM scale ranges from 13 (extreme evening owl) to 65 (extreme morning larks). Furthermore, we tested the reliability of this measure in the Chinese version using Cronbach's alpha [114]. Hinton et al. [115] proposed four interval-based categories to assess the reliability of a summative scale [116], which consist of excellent reliability (0.90 and above), high reliability (0.70-0.90), moderate reliability $(0.50-0.70)$, and low reliability $(0.50$ and below). The Cronbach's alpha for the Chinese adaptation of the CSM was 0.879, indicating that it is highly reliable, and this value is very close to that of the original English version of the CSM [29; Cronbach's alpha $=0.87$ ]. Finally, we categorized the continuum of the CSM values into three chronotypes, following Smith et al. [29]. We have 60 observations of morning-types (44 and above), 384 observations of intermediate-types (23-43), and only six observations of evening-types (22 and less). The three chronotype samples in our study are not evenly distributed. In particular, our sample is represented by 13.18 percent, 84.62 percent, and 2.20 percent following the morningness, intermediate, and eveningness classification, which indicates that the majority are intermediate type. By comparison, we note that our sample distribution is similar to those by Lau et al. [117] and Wong et al. [118] that also used the CSM scale. The distribution of their sample according to morningness, intermediate and evening classification is 7.12 percent, 85.87 percentm, and 7.01 percent and 2.5 percent, 84.8 percent, and 12.7 percent, respectively. Consequently, we address the difference in distribution by carrying out further tests using the adopted cut-off criteria proposed by Wong et al. [119], which is eveningness, intermediate, and morningness at 22 and below, 23-40, and 41 and above, respectively. Our robustness test reveal that the results are similar to those in Appendix B with the exception that the circadian rhythm scale is replaced by the newly categorized morningness. All the remaining results support the hypothesised relationships. Because of the very few observations of evening type, we re-categorized the sample to generate one binary variable, where one indicates morning-type while zero denotes non-morning-type.

Time preference. We use a combination of intertemporal behaviour to proxy time preference, as proposed by Finke and Huston [30], who constructed a summative scale using eight items, each representing one behaviour, with outcomes at different time points. The reason is to choose this method is that Finke and Huston [30] showed that this additive index is a strong predictor for measuring time discounting compared with traditional measurements in which respondents are asked to choose between receiving a small amount of money right now or a larger amount of money in the future. We also invited a native Chinese speaker who was proficient in both English and Chinese to translate these questions. Participants sequentially answered seven of eight questions about wearing a seatbelt when driving a car, smoking, drinking wine, using nutrition labels when shopping for food, engaging in arduous physical exercise, unprotected sex behaviour, and choosing food for the purpose of maintaining diet. Nevertheless, the last question was dropped, which asked whether the respondent used drugs or any controlled substances. Because both the recreational and medical use of marijuana or cannabis are banned and severely enforced throughout China [120], this question was not appropriate. Respondents were asked to respond on a five-point Likert scale ranging from "never" to "always". For positive behaviour, such as wearing the seatbelt when driving a car, we coded 1 for those who never wear the seatbelt and 5 for those who always wear it. In contrast, for negative behaviour, such as consuming wine, we coded 1 for those drink wine almost every day and 5 for those who never consume alcoholic drinks. Hence, this additive scale ranges from 7 to 35 , where higher scores represent individuals who emphasize future goal attainment and delay gratification. The Cronbach's alpha for this Chinese version time perspective scale was 0.573 , indicating that it is moderately reliable.

Risk preference. We use one simple and behaviourally valid survey question to measure risk attitudes in a financial context, following Dohmen et al. [26]. Although economists question whether self-reported individual preference and traits are behaviourally meaningful due to incentive compatibility, Dohmen et al. [26] reported that this measure maps onto actual monetary outcomes from lottery choice experiments [121,122], which in turn give us confidence in using this survey question to elicit risk attitudes. This question directly asks respondent to make a general assessment regarding 
their willingness to take financial risk: "How willing are you to take risks, in financial matters?" Participants rate their financial risk attitude from 0 to 10 . More importantly, this measure is empirically valid in explaining individual differences in financial decision, such as investments in stock, in a large representative survey. We also translated this question into Chinese, as we distributed this survey in Mainland China.

Financial behaviour. We aim to investigate whether and how the circadian typologies may influence individual's credit behaviour, such as delinquent credit card payments. We asked the respondents one simple question: "Please indicate below the option that best describes your payments on credit cards." Six exclusive options are available $[123,124]$, including "I do not use credit cards for payments" (0), "Always pays off monthly" (1), "Generally pays off monthly" (2), "Occasionally pays off monthly" (3), "Seldom pays off, but tries to pay down" (4), and "Generally pays minimum each month" (5). We deleted the observations, which selected "I do not use credit cards for payments" and then recoded zero for respondents providing the answer "Always pays off monthly" and one for the other answers. We also examine whether and how circadian rhythms affect individuals' investment behaviour, such as willingness to participate in the stock market. We asked one simple question: "Have you ever invested in stock market?" Two options are provided. We scored one if respondents answer "Yes" and score zero if respondents answer "No". These questions were translated into Chinese when distributing the surveys to the respondents.

Control variables. To reduce omitted variable bias when estimating the effect of morningnesseveningness on the preference constructs and in turn financial behaviour (i.e., revolving credit card debt and investments in stock), we included demographic information in the survey. Specifically, the survey included age, gender, marital status, education, and monthly income [21,24,53,122,125-129]. We measure age with a single question "What is your age?" Respondents were provided with three options, "18 to 29 years old", " 30 to 44 years old", and " 45 to 54 years old", which are marked from 1 to 3 . Male is dichotomously measured, where one indicates male and zero otherwise. Marital status is also a binary variable, where one indicates married and zero otherwise. Educational attainment is an ordinal variable that ranges from one to six, denoting "Lower than high school", "High school", "College", "Bachelor's degree", "Master's degree", and "Doctoral degree", respectively. The measurement of monthly income is a single question: "What is your monthly income?" Respondents were provided with six options, consisting of "Less than 3000", "3000 to 5000", "5000 to 7500", "7500 to 10,000", "10,000 to 20,000", and "More than 2000", which are marked from 1 to 6, respectively. The units are RMB. We translated these questions into Chinese when distributing the surveys. To summarize, these variables are possibly exogenous with respect to individual preferences and financial behaviour, and can therefore, which is used to help interpret links in the regression estimates.

To view the original questions for these measurements, please see Appendix A.

\subsection{Data Description}

Table 1 reports descriptive statistics of the measured variables. The distribution of respondents in the circadian typology groups was 60 in the morning type (13.19\%) and 395 in the non-morning-type $(86.81 \%)$. The distribution of time preference scores (skewness $=-0.522$; Kurtosis $=4.043$ ) and financial risk preferences (skewness $=-0.857$; Kurtosis $=3.636$ ) were both left-skewed; thus, the results associated with these measures must be treated carefully. A total of $65.7 \%$ and $34.1 \%$ of the respondents invest in the stock market and have the credit card debt, respectively. In addition, we have a relatively gender-balanced sample (177 men and 278 women).

The Pearson's correlation matrix of the variables is shown in Table 2. The correlation analysis supported the majority of the proposed hypotheses. As expected, morning larks are prone to being future-oriented $(\mathrm{r}=0.262, p<0.01)$ and are less likely to have unpaid credit card debt $(\mathrm{r}=-0.157$, $p<0.01)$. Second, morning-oriented people are more risk taking $(\mathrm{r}=0.131, p<0.01)$ and in turn are more likely to invest in the stock market $(r=0.303, p<0.01)$. 
Table 1. Descriptive statistics of the study's variables.

\begin{tabular}{lccccc}
\hline \multicolumn{1}{c}{ Variables } & Observations & Mean & SE & Min & Max \\
\hline Morningness & 455 & 0.132 & 0.339 & 0 & 1 \\
Age & 455 & 1.378 & 0.485 & 1 & 2 \\
Male & 455 & 0.389 & 0.488 & 0 & 1 \\
Married & 455 & 0.752 & 0.432 & 0 & 1 \\
Education & 455 & 3.936 & 0.558 & 1 & 6 \\
Monthly income & 455 & 3.342 & 1.105 & 1 & 6 \\
Time preference & 455 & 25.164 & 2.959 & 13 & 32 \\
Financial risk preference & 455 & 7.569 & 1.926 & 1 & 11 \\
Stock market participation & 455 & 0.657 & 0.475 & 0 & 1 \\
Delinquent credit card payments & 455 & 0.341 & 0.474 & 0 & 1 \\
\hline
\end{tabular}

Table 2. Pearson's correlation coefficients for key study variables.

\begin{tabular}{|c|c|c|c|c|c|c|c|c|c|}
\hline Variables & 1 & 2 & 3 & 4 & 5 & 6 & 7 & 8 & 9 \\
\hline \multicolumn{10}{|l|}{ 1. Morningness } \\
\hline 2. Age & 0.058 & & & & & & & & \\
\hline 3. Male & -0.058 & -0.036 & & & & & & & \\
\hline 6. Monthly income & 0.067 & $0.152^{* * * *}$ & $0.112 * *$ & $0.183^{* * *}$ & $0.354^{* * *}$ & & & & \\
\hline 7. Time preference & $0.262 * * *$ & $0.104^{* *}$ & $-\underset{* * *}{0.167}$ & 0.020 & $0.188^{* * *}$ & 0.037 & & & \\
\hline 8. Financial risk preference & $0.131^{* * *}$ & 0.002 & $0.200 * * *$ & 0.088 & 0.042 & $0.240^{* * *}$ & 0.080 & & \\
\hline
\end{tabular}

To test the level of collinearity, we calculated the variance inflation factors for the variables, and they are all smaller than 2 , suggesting that the level of collinearity is not problematic [130]. To further examine the relationships between the key variables of interest, we use the independent group t-test to examine mean difference on concerned variables between morning-types and non-morning-types. Specifically, morning-types scored higher on time perspective $(M=27.150$; $S D=0.345)$ than non-morning-types $(\mathrm{M}=24.863 ; \mathrm{SD}=0.145), \mathrm{t}(453)=5.771, p<0.001$, difference $=2.29)$ and they had a higher level of financial risk taking $(\mathrm{M}=8.217 ; \mathrm{SD}=0.257$, vs. $\mathrm{M}=7.471 ; \mathrm{SD}=0.096, \mathrm{t}(453)=2.816$, $p<0.001$, difference $=0.746$ ) .

\subsection{Econometrics Model}

To test the direct effect of morningness on delinquent credit card payments (Hypothesis 1 ) and on investments in stock (Hypothesis 5), we use a logistic regression model, since delinquent credit card payments and investments in stock are dichotomously-measured dependent variables. Additionally, logistic regression also has a number of advantages. First, neither the dependent nor the independent variables have to be normally distributed. Similarly, logistic regression does not assume that the error terms have to be in normal distribution. More importantly, it does not assume that the relationships between the independent and dependent variables are linear.

We specify the following logistic models to test the relationship between morning-type and delinquent credit card payments (Hypothesis 1):

$$
\text { Delinquent credit card payment }{ }_{i}=\beta_{0}+\beta_{1} \text { Morningness }+\beta_{2} \text { Time preference }+\sum_{k=5}^{K} \beta_{k} X_{i k}+\epsilon_{i}
$$

where $X_{i k}$ is the set of control variables of individual $i$, including age, male, marital status, education, and monthly income. $\epsilon_{i}$ is the error term.

The model specification to examine the link between morning-type and stock ownership is as follows (Hypothesis 5): 


$$
\text { Owning stock } k_{i}=\beta_{0}+\beta_{1} \text { Morningness }+\beta_{2} \text { Finanical risk prefernce }+\sum_{k=5}^{K} \beta_{k} X_{i k}+\epsilon_{i}
$$

where $X_{i k}$ is a vector of control variables of individual $i$, including age, male, marital status, education, and monthly income. $\epsilon_{i}$ is the error term.

To test the moderating role of income on the link between time preference and delinquent credit card debt (Hypothesis 3), we use a logistic regression model with an interaction item (Time preference $x$ Monthly income), as delinquent credit card debt is a dichotomous variable. The model specification is:

$$
\begin{aligned}
& \text { Delinquent credit card debt } \\
& \qquad \begin{array}{l}
=\beta_{0}+\beta_{1} \text { Time preferece }+\beta_{2} \text { Time preference } \times \text { Monthly income } \\
+\beta_{3} \text { Monthly income }+\sum_{k=4}^{K} \beta_{k} X_{i k}+\epsilon_{i}
\end{array}
\end{aligned}
$$

where $X_{i k}$ is a vector of control variables of individual $i$, including age, male, marital status, and education. $\epsilon_{i}$ is the error term.

To test the moderating role of income on the link between morning type and financial risk preference (Hypothesis 7), we use an ordinary least squares regression model with an interaction item (Morning type $\times$ Monthly income). The model specification is:

$$
\begin{aligned}
& \text { Financial risk preference }{ }_{i} \\
& \qquad \begin{array}{l}
=\beta_{0}+\beta_{1} \text { Morning type }+\beta_{2} \text { Morning type } \times \text { Monthly income } \\
+\beta_{3} \text { Monthly income }+\sum_{k=4}^{K} \beta_{k} X_{i k}+\epsilon_{i}
\end{array}
\end{aligned}
$$

where $X_{i k}$ is a vector of control variables of individual $i$, including age, male, marital status, and education. $\epsilon_{i}$ is the error term.

To test above hypotheses, we used Stata 15.1.

Next, we used path analysis to test whether time perspective mediates the relationship between morning-type and delinquent credit card payments (Hypothesis 2) and whether financial risk attitude mediates the link between morning-type and investments in stock (Hypothesis 6). To test these mediation models, we used the PROCESS 2.16 .3 macro [131] in SPSS 24.0 and conducted bootstrapping with 5000 resampling to verify the statistical significance. Furthermore, we also used path analysis within the PROCSS macro to investigate the moderating role of income on the indirect effect between morningness and delinquent credit card payments through time preference, on the path from time preference to delinquent credit card payments (Hypothesis 4). Similarly, we applied this method to examine whether income affects the indirect effect of morningness on stock ownership through financial risk preference on path from morningness to financial risk preference (Hypothesis 8).

\section{Results}

\subsection{Direct Effect of Morning Chronotype on the Likelihood of Having Revolving Credit Card Debt (H1)}

Table 3 reports the average marginal effect of morningness on delinquent credit card payments that are based on the logistic regression. The independent variable is morningness, indicating the morning type of circadian chronotypes. The results indicate that morning types are negatively associated with delinquent credit card payments. In other words, when compared with the other chronotypes, the percentage of having delinquent credit card payments for morningness people is $22.3 \%$ lower. Although we control for age, male, marital status, education, monthly-income, and time preference, only time preference is significant in predicting the variance of delinquent credit card payment. In summary, the results indicate that morning types attenuate revolving credit card payments, which are in support of Hypothesis 1. 
Table 3. Reports the average marginal effect of morningness on delinquent credit card payment in logistic regression.

\begin{tabular}{|c|c|c|c|c|}
\hline \multirow{2}{*}{$\begin{array}{c}\text { Dependent Variable: Delinquent } \\
\text { Credit Card Payments } \\
\text { Variables }\end{array}$} & \multicolumn{4}{|c|}{ Logistic Regression } \\
\hline & Average Marginal Effect & SE & z-Statistic & $p$-Value \\
\hline \multicolumn{5}{|l|}{ Main variables } \\
\hline Morningness & $-0.223^{* * *}$ & 0.080 & -2.80 & 0.005 \\
\hline \multicolumn{5}{|l|}{ Control variables } \\
\hline Age & 0.005 & 0.048 & 0.10 & 0.917 \\
\hline Male & -0.016 & 0.046 & -0.37 & 0.712 \\
\hline Married & 0.028 & 0.053 & 0.53 & 0.593 \\
\hline Education & -0.035 & 0.043 & -0.82 & 0.412 \\
\hline Monthly income & 0.031 & 0.023 & 1.36 & 0.174 \\
\hline Time preference & $-0.019^{* *}$ & 0.008 & -2.31 & 0.021 \\
\hline Log pseudolikelihood & -280.78662 & & & \\
\hline Pseudo R2 & 0.038 & & & \\
\hline Number of observations & 455 & & & \\
\hline
\end{tabular}

\subsection{The Mediating Role of Time Perspective (H2)}

First, we use OLS regression to investigate the relationship between morningness and time preference. Second, a logistic regression is performed to examine the relationship between time preference and delinquent credit card payments. Consequently, we are able to test whether time preference mediates the link between morningness and delinquent credit card payments (Hypothesis 3). Table 4 reports the results of this mediation model. The results indicate that the morning chronotype is positively associated with time preference (path a: coefficient is $2.136, \mathrm{SE}=0.375, \mathrm{t}=5.701$ ) and time preference is negatively associated with delinquent credit card payments (path $b$ : coefficient is -0.087 , $\mathrm{SE}=0.037, \mathrm{z}=-2.367$ ). Since a-path and b-path are both significant, which indicates that there is a mediation effect. To further test the significance of this mediation effect (indirect effect $a \times b$ ), we use the bootstrapping method with bias-corrected confidence estimates [132]. Subsequently, the $95 \%$ confidence interval of the indirect effect is taken with 5000 bootstraps resamples [132]. If the confidence interval of the estimator does not contain 0 , then it indicates that the indirect effect is significantly different from zero. The results of the bootstrap test show that time preference mediates the link between morningness and the delinquent credit card payments (indirect effect $=\mathrm{a} \times \mathrm{b}=-0.186, \mathrm{SE}=0.092,95 \% \mathrm{CI}=$ from -0.381 to -0.029 ). Moreover, when adding time preference, the relationship between the morning chronotype and delinquent credit card payments is still significant (path $c^{\prime}$ : coefficient is -1.045 , $\mathrm{SE}=0.386, \mathrm{z}=-2.704$ ). This results means that time preference is a partial mediator. To summarize, the results are in support of Hypothesis 2. In other words, we find that time preference is one channel through which morningness negatively influences the likelihood of delinquent credit card payments. 
Table 4. The mediating effect of time preference on the relationship between morningness and delinquent credit card payments.

\begin{tabular}{|c|c|c|c|c|c|c|}
\hline \multirow[b]{2}{*}{ Variables } & \multicolumn{3}{|c|}{ Time Preference } & \multicolumn{3}{|c|}{ Delinquent Credit Card Payments } \\
\hline & Coefficient & SE & $\mathbf{t}$ & Coefficient & SE & $\mathbf{z}$ \\
\hline Constant & $20.912 * * *$ & 1.051 & 19.890 & 1.684 & 1.092 & 1.543 \\
\hline Morningness & $2.136 * * *$ & 0.375 & 5.701 & $-1.045^{* * *}$ & 0.386 & -2.704 \\
\hline Age & $0.557 * *$ & 0.273 & 2.039 & 0.023 & 0.221 & 0.106 \\
\hline Male & $-0.904 * * *$ & 0.272 & -3.324 & -0.078 & 0.214 & -0.365 \\
\hline Married & -0.169 & 0.337 & -0.500 & 0.132 & 0.253 & 0.522 \\
\hline Education & $1.029 * * *$ & 0.293 & 3.511 & -0.164 & 0.196 & -0.837 \\
\hline Monthly income & -0.110 & 0.162 & -0.682 & 0.145 & 0.102 & 1.415 \\
\hline Time preference & & & & $-0.087 * *$ & 0.037 & -2.367 \\
\hline R2 & 0.133 & & & & & \\
\hline Pseudo R2 & & & & 0.038 & & \\
\hline Number of observations & 455 & & & 455 & & \\
\hline Mediator Time preference & Bootstrapping effect & & Boot SE & & $95 \% \mathrm{C}$ & LL, UL) \\
\hline Indirect effect & -0.186 & & 0.090 & & -0.381 & -0.029 \\
\hline
\end{tabular}

Note: Unstandardized regression coefficients are reported; bootstrap sample size $=5000$. $\mathrm{CI}=$ confidence interval;

$\mathrm{LL}=$ lower limit; $\mathrm{UL}=$ upper limit. ${ }^{* *}$ indicates $p<0.05$, and ${ }^{* * *}$ indicates $p<0.01$.

4.3. The Moderating Role of Income on the Indirect Effect of Morningness on Delinquent Credit Card Payments (H3 and H4)

Table 5 summarizes the statistical results of the moderation model that investigates the moderating effect of monthly income on the relationship between time preference and delinquent credit card payments. The dependent variable is delinquent credit card payments. The independent variable is time preference, and the moderator is monthly income. We grand-mean-center the moderator (Monthly income) and the independent variable (Time preference) according to the approach that was proposed by Aiken et al. [133]. In particular, after the effects of the control variables and the main effects of time preference are accounted, we find that the coefficient of the cross product between monthly income and time preference is $0.062, \mathrm{t}=2.228, p=0.026$, yielding a significant interaction effect in relation to delinquent credit card payments. The results support Hypothesis 3.

Table 5. The moderation effect of monthly income on the relationship between time preference and delinquent credit card payments.

\begin{tabular}{|c|c|c|c|c|}
\hline \multirow{2}{*}{$\begin{array}{c}\text { Dependent Variables: Delinquent Credit Card Payments } \\
\text { Variables }\end{array}$} & \multicolumn{4}{|c|}{ Monthly Income as a Moderator in Logistic Regression } \\
\hline & Coefficients & SD & z-Statistic & $p$-Value \\
\hline Constant & -0.047 & 0.874 & -0.05 & 0.957 \\
\hline Age & 0.084 & 0.226 & 0.37 & 0.711 \\
\hline Male & -0.088 & 0.213 & -0.41 & 0.680 \\
\hline Married & 0.096 & 0.253 & 0.38 & 0.704 \\
\hline Education & -0.174 & 0.198 & -0.88 & 0.379 \\
\hline Morningness & $-1.118 * * *$ & 0.394 & -2.84 & 0.005 \\
\hline Monthly income & $0.190 *$ & 0.107 & 1.78 & 0.075 \\
\hline Time preference & $-0.106^{* * *}$ & 0.038 & -2.78 & 0.005 \\
\hline Monthly income $\times$ Time preference & $0.062 * *$ & 0.026 & 2.37 & 0.018 \\
\hline Log pseudolikelihood & -278.24058 & & & \\
\hline Pseudo R2 & 0.047 & & & \\
\hline Number of observations & 455 & & & \\
\hline
\end{tabular}

Note: The dependent variable is delinquent credit card payments. Monthly income is the moderator. This table reports the coefficients from the logistic regression examining the moderating effect of monthly income on the relationship between time preference and delinquent credit card payment. The sample includes residents of China who have been working for three to eight years, randomly sampled using an online survey. ${ }^{*}, * *$ and ${ }^{* * *}$ indicate significant at $10 \%$ level (2-sided), 5\% level, and 1\% level, respectively.

To explore the indirect relationship between morningness and delinquent credit card payments through time preference would be conditional on the moderator variable of monthly income for the path from time preference to delinquent credit card payments, we use the bootstrap methods that were proposed by Hayes [131] to test this hypothesized second-stage moderated mediation model (Hypothesis 4). The first step is to examine the interactive effect of time preference and monthly 
income on delinquent credit card payments. The results suggest that the interaction term between monthly income and time preference is significant $(b=0.062, p<0.05)$. Table 6 displays the details. The second step is to investigate the conditional indirect effects at 1 standard deviation above (high monthly income), at 0 standard deviation from (average monthly income), and at 1 standard deviation below the mean of the moderator (low monthly income). Table 6 reports the details of the moderated mediation model test.

Table 6. The conditional indirect effect of morningness on delinquent credit card payments.

\begin{tabular}{|c|c|c|c|c|c|c|}
\hline \multirow[b]{2}{*}{ Variables } & \multicolumn{3}{|c|}{ Time Preference } & \multicolumn{3}{|c|}{ Delinquent Credit Card Payment } \\
\hline & Coefficient & SE & $\mathbf{t}$ & Coefficient & SE & $\mathbf{z}$ \\
\hline Constant & $-4.245^{* * *}$ & 1.053 & -4.033 & -0.047 & 0.866 & -0.054 \\
\hline Age & $0.532 *$ & 0.278 & 1.912 & 0.084 & 0.223 & 0.376 \\
\hline Male & $-0.936^{* * *}$ & 0.274 & -3.413 & -0.088 & 0.215 & -0.410 \\
\hline Married & -0.213 & 0.328 & -0.649 & 0.096 & 0.255 & 0.376 \\
\hline Education & $0.954^{* * * *}$ & 0.262 & 3.643 & -0.174 & 0.197 & -0.884 \\
\hline Morningness & $2.116^{* * *}$ & 0.368 & 5.745 & $-1.118 * * *$ & 0.392 & -2.858 \\
\hline Monthly income & & & & 0.191 * & 0.105 & 1.817 \\
\hline Time preference & & & & $-0.106^{* * *}$ & 0.038 & -2.765 \\
\hline $\begin{array}{l}\text { Monthly income } \times \text { Time } \\
\text { preference }\end{array}$ & & & & $0.062 * *$ & 0.028 & 2.228 \\
\hline $\mathrm{R} 2$ & 0.131 & & & & & \\
\hline Pseudo R2 & & & & 0.047 & & \\
\hline Number of observations & 455 & & & 455 & & \\
\hline Moderator: Monthly income & Bootstrapping indirect effect & & Boot SE & & $95 \% \mathrm{CI}$ & L, UL) \\
\hline Low (-1 SD from mean) & -0.368 & & 0.138 & & -0.666 & -0.139 \\
\hline Average (0 SD from mean) & -0.224 & & 0.094 & & -0.430 & -0.062 \\
\hline High (+1 SD from mean) & -0.079 & & 0.097 & & -0.283 & 0.104 \\
\hline $\begin{array}{l}\text { Index of moderated } \\
\text { mediation }\end{array}$ & & & & & & \\
\hline Mediator & Index & Boot SE & & & $95 \% \mathrm{CI}$ & L, UL) \\
\hline Time preference & 0.131 & 0.067 & & & 0.012 & 0.270 \\
\hline
\end{tabular}

In particular, for low monthly income, the moderated mediation model is significant (indirect effect $=-0.368, \mathrm{SE}=0.138,95 \% \mathrm{CI}=[-0.666,-0.139])$. Therefore, morning-type people with low monthly income have less likelihood of delinquent credit card payments by 0.368 . Similarly, for average monthly income, the moderated mediation model is also significant (indirect effect $=0.224, \mathrm{SE}=0.094$, $95 \% \mathrm{CI}=[-0.430,-0.062])$. Hence, morning-type people with average monthly income have a propensity for decreasing the likelihood of delinquent credit card payment by 0.224 . However, for high monthly income, the moderated mediation model is not significant (indirect effect $=-0.079, \mathrm{SE}=0.097$, $95 \% \mathrm{CI}=[-0.283,0.104])$. The index of moderated mediation [134] quantifies this conditional indirect effect $(b=0.131, \mathrm{SE}=0.067,95 \% \mathrm{CI}=[0.012,0.270])$. Together, the results indicate that morningness is more likely to influence delinquent credit card payment behaviour through time preference when income is at low and average levels.

To summarize, their findings above indicate that the morning chronotype influences delinquent credit card payments through time preference, and that the indirect effects change according to different levels of monthly income.

\subsection{The Direct Effect of Morningness on the Likelihood of Investments in Stock (H5)}

Table 7 reports the average marginal effect of morningness on stock market participation using a logistic regression. The independent variable is morningness, indicating the morning type of circadian chronotypes. The results indicate that morning type is not positively associated with stock market participation (average marginal effect of morningness is $0.105, \mathrm{SE}=0.063$, z-statistics $=1.66$, $p=0.098$ ). In other words, when comparing with other chronotypes, the percentage of owning stock for morningness people is not significant from zero. In summary, the results do not support Hypothesis 5. 
Table 7. The effect of morningness on stock market participation based on logistic regression.

\begin{tabular}{|c|c|c|c|c|}
\hline $\begin{array}{l}\text { Dependent Variables: } \\
\text { Stock Market Participation }\end{array}$ & Logistic Regression & & & \\
\hline Variables & Average Marginal Effect & SE & z-Statistic & $p$-Value \\
\hline \multicolumn{5}{|l|}{ Main variables } \\
\hline Morningness & $0.105^{*}$ & 0.063 & 1.66 & 0.098 \\
\hline \multicolumn{5}{|l|}{ Control variables } \\
\hline Age & 0.011 & 0.044 & 0.24 & 0.812 \\
\hline Male & $0.111^{* *}$ & 0.045 & 2.49 & 0.013 \\
\hline Married & $0.088^{*}$ & 0.047 & 1.83 & 0.067 \\
\hline Education & $0.121^{* * *}$ & 0.037 & 3.24 & 0.001 \\
\hline Monthly income & 0.018 & 0.021 & 0.86 & 0.389 \\
\hline Financial risk preference & 0.056 ** & 0.011 & 5.24 & 0.001 \\
\hline Log pseudolikelihood & -258.340 & & & \\
\hline Pseudo R2 & 0.117 & & & \\
\hline Number of observation & \multicolumn{4}{|c|}{455} \\
\hline
\end{tabular}

Note: The dependent variable is stock market participation. This table reports the average marginal effect based on logistic regression examining the effect of morningness on the stock market participation. The sample is China residents who have been working for 3 to 8 years, randomly sampled with the online survey. ${ }^{*}, * *$, and ${ }^{* * *}$ indicate significance at $10 \%$ level (two-sided), $5 \%$ level, and $1 \%$ level, respectively.

\subsection{The Mediating Role of Financial Risk Preference (H6)}

First, an OLS regression is used to investigate the relationship between morningness and financial risk preference. Second, a logistic regression is conducted to examine the relationship between financial risk preference and stock market participation. Consequently, we are able to test whether financial risk preference mediates the link between morningness and stock market participation (Hypothesis 6). Table 8 reports the results of this mediation model. The results indicate that the morning chronotype is positively associated with financial risk preference (path a: coefficient is $0.745, \mathrm{SE}=0.277, \mathrm{t}=2.688$ ). This finding contradicts that of Wang and Chartrand [25]. In addition, financial risk tolerance is positively associated with stock market participation (path $\mathrm{b}$ : coefficient is $0.293, \mathrm{SE}=0.059, \mathrm{z}=4.934$ ). Since the a-path and b-path are significant, the results indicate that there is a mediation effect. To further test the significance of this mediation effect (indirect effect $a \times b$ ), we use the bootstrapping method with bias-corrected confidence estimates [132]. Next, the $95 \%$ confidence interval of the indirect effect is taken with 5000 bootstraps resamples [132]. If the confidence interval of the estimator does not contain 0 , it shows that the indirect effect is significantly different from zero. The results of the bootstrap test showed that financial risk preference mediates the link between morningness and stock market participation (indirect effect $=\mathrm{a} \times \mathrm{b}=0.219, \mathrm{SE}=0.095,95 \% \mathrm{CI}=$ from 0.067 to 0.435 ). Moreover, when adding financial risk preference, the relationship between the morning chronotype and stock market participation turns becomes non-significant (path c': coefficient is $0.543, \mathrm{SE}=0.351$, $\mathrm{z}=1.551$ ). This result means that financial risk preference is a full mediator. To summarize, the results are in support of Hypothesis 6. In other words, financial risk preference is one channel through which morningness positively influences the likelihood of stock market participation. 
Table 8. The mediating effect of financial risk preference on the relationship between morningness and stock market participation.

\begin{tabular}{|c|c|c|c|c|c|c|}
\hline \multirow[b]{2}{*}{ Variables } & \multicolumn{3}{|c|}{ Financial Risk Preference } & \multicolumn{3}{|c|}{ Stock Market Participation } \\
\hline & Coefficient & SE & $t$ & Coefficient & SE & $\mathbf{z}$ \\
\hline Constant & $6.514^{* * *}$ & 0.654 & 9.953 & $-4.978^{* * *}$ & 0.962 & -5.175 \\
\hline Morningness & $0.745^{* * *}$ & 0.277 & 2.688 & 0.543 & 0.351 & 1.551 \\
\hline Age & -0.225 & 0.189 & -1.192 & 0.055 & 0.234 & 0.233 \\
\hline Male & $0.750^{* * *}$ & 0.179 & 4.186 & $0.577^{* *}$ & 0.234 & 2.471 \\
\hline Married & 0.375 & 0.232 & 1.619 & $0.455 *$ & 0.258 & 1.768 \\
\hline Education & -0.147 & 0.164 & -0.896 & $0.629 * * *$ & 0.212 & 2.976 \\
\hline Monthly income & $0.381^{* * *}$ & 0.093 & 4.080 & 0.095 & 0.109 & 0.869 \\
\hline Financial risk preference & & & & $0.293^{* * *}$ & 0.059 & 4.934 \\
\hline R2 & 0.113 & & & & & \\
\hline Pseudo R2 & & & & 0.117 & & \\
\hline Number of observations & 455 & & & 455 & & \\
\hline $\begin{array}{l}\text { Mediator Financial } \\
\text { preference }\end{array}$ & Bootstrapping effect & & Boot SE & & $95 \% \mathrm{C}$ & L, UL) \\
\hline Indirect effect & 0.219 & & 0.095 & & 0.067 & 0.435 \\
\hline
\end{tabular}

4.6. The Moderating Role of Income on the Indirect Effect of Morningness on Stock Market Participation ( $\mathrm{H7}$ and $\mathrm{H} 8$ )

Table 9 summarizes the statistical results of the moderation model that investigates the moderating effect of monthly income on the relationship between morningness and financial risk preference. The dependent variable is financial risk preference. The independent variable is morningness and the moderator is monthly income. We grand-mean-center the moderator (Monthly income) and the independent variable (Morningness) according to the approach proposed by Aiken et al. [133]. In particular, after the effects of the control variables and the main effects of time preference are accounted, we find that the coefficient of cross product between monthly income and morningness is $0.209, \mathrm{SE}=0.286, \mathrm{t}=0.73, p=0.463$, indicating that there is no significant interaction effect in relation to stock market participation. The results do not support Hypothesis 7.

Table 9. The moderation effect of monthly income on the relationship between morningness and financial risk preference.

\begin{tabular}{lcccc}
\hline $\begin{array}{c}\text { Dependent Variables: } \\
\text { Financial Risk Preference }\end{array}$ & \multicolumn{3}{c}{ Monthly Income as a Moderator in Ordinary Least } \\
Squares Regression
\end{tabular}

Note: The dependent variable is financial risk preference. Monthly income is the moderator. This table reports the coefficients from the OLS regression examining the moderating effect of monthly income on the relationship between morningness and financial risk preference. The sample is China residents who have been working for 3 to 8 years, randomly sampled with the online survey. ${ }^{*}$ and ${ }^{* * *}$ indicate significances at the $10 \%$ level (two-sided) and $1 \%$ level, respectively.

To explore whether the indirect relationship between morningness and stock market participation through financial risk preference would be conditional on the moderator variable of monthly income 
for the path from morningness to financial risk preference, we use the bootstrap methods proposed by Hayes [131] to test this hypothesized first-stage moderated mediation model (Hypothesis 8). The first step is to examine the interactive effect of morningness and monthly income on financial risk preference. The results suggest that the interaction term between morningness and monthly income is not significant $(b=0.210, \mathrm{SE}=0.305, \mathrm{t}=0.688, p>0.05)$. The second step is to investigate the conditional indirect effects at one standard deviation above (high monthly income), at 0 standard deviation from (average monthly income), and at one standard deviation below the mean of the moderator (low monthly income). Table 10 reports the details of the moderated mediation model test.

Table 10. The conditional indirect effect of morningness on stock market participation.

\begin{tabular}{|c|c|c|c|c|c|c|}
\hline \multirow[b]{2}{*}{ Variables } & \multicolumn{3}{|c|}{ Financial Risk Preference } & \multicolumn{3}{|c|}{ Stock Market Participation } \\
\hline & Coefficient & SE & $t$ & Coefficient & SE & $\mathbf{z}$ \\
\hline Constant & $7.866^{* * *}$ & 0.722 & 10.899 & $-4.974^{* * *}$ & 0.962 & -5.168 \\
\hline Age & -0.232 & 0.188 & -1.231 & 0.077 & 0.233 & 0.330 \\
\hline Male & $0.766^{* * *}$ & 0.183 & 4.180 & $0.600 * * *$ & 0.232 & 2.587 \\
\hline Married & 0.381 & 0.232 & 1.647 & $0.487 *$ & 0.255 & 1.912 \\
\hline Education & -0.144 & 0.164 & -0.876 & $0.693^{* * *}$ & 0.199 & 3.474 \\
\hline Morningness & $0.713^{* *}$ & 0.280 & 2.545 & 0.549 & 0.351 & 1.566 \\
\hline Monthly income & $0.379^{* * *}$ & 0.093 & 4.070 & & & \\
\hline Financial preference & & & & $0.303^{* * *}$ & 0.059 & 5.174 \\
\hline Monthly income $\times$ Morning type & 0.210 & 0.305 & 0.688 & & & \\
\hline R2 & 0.115 & & & & & \\
\hline Pseudo R2 & & & & 0.116 & & \\
\hline Number of observations & 455 & & & 455 & & \\
\hline Moderator: Monthly income & Bootstrapping indirect effect & & Boot SE & & $95 \% \mathrm{CI}$ & $\mathrm{L}, \mathrm{UL})$ \\
\hline Low (-1 SD from mean) & 0.146 & & 0.136 & & -0.100 & 0.444 \\
\hline Average (0 SD from mean) & 0.216 & & 0.095 & & 0.054 & 0.422 \\
\hline High (+1 SD from mean) & 0.286 & & 0.147 & & 0.047 & 0.620 \\
\hline Index of moderated mediation & & & & & & \\
\hline Mediator & Index & $\begin{array}{c}\mathrm{SE} \\
\text { (Boot) }\end{array}$ & & & $95 \% \mathrm{CI}$ & $\mathrm{L}, \mathrm{UL})$ \\
\hline Financial preference & 0.064 & 0.095 & & & -0.107 & 0.279 \\
\hline
\end{tabular}

Note: Unstandardized regression coefficients are reported; bootstrap sample size $=5000 . \mathrm{CI}=$ confidence interval;

$\mathrm{LL}=$ lower limit; $\mathrm{UL}=$ upper limit. ${ }^{*}$ indicates $p<0.1{ }^{* *}$ indicates $p<0.05$, and ${ }^{* * *}$ indicates $p<0.01$.

Since the interaction between morningness and monthly income is not significant and the index of moderated mediation model is not significant (Index $=0.064, \mathrm{SE}=0.095,95 \% \mathrm{CI}=[-0.107,0.279]$ ), the results indicate that there is no conditional indirect effect between morningness and stock market participation through financial risk preference.

To summarize, the findings above indicate that morning chronotype influences stock market participation fully through financial risk preference and that these indirect effects do not vary at different levels of monthly income.

\subsection{Robustness Check}

We changed the dichotomously measured morningness in the benchmark analysis to a continuum scale, because Chelminski et al. [135] proposed the idea of using continuum scale of morningness-eveningness, which may provide richer information regarding the hypothesized relationships. We also used a different single question that was also proposed by Dohmen et al. [26] to measure risk preference, which can generate an all-around factor to predict risky behaviour. In addition, we added both risk and time preference measures in all settings of the regression and path analyses, as risk and time are intertwined. It would be problematic to isolate risk attitude when studying time preference [136], because uncontrolled risk preference can create present-biased choices or behaviour. By changing the measures of the key variables of interests and increasing bootstrap sample size from 5000 to 50,000, we intend to verify the robustness of our results.

The analysis first shows that circadian rhythm is negatively associated delinquent credit debt payments, and time perspective partially mediates this relationship. In addition, income moderates 
this indirect effect on the path from time preference to delinquent credit debt payments. Second, risk preference still fully mediates the positive association between circadian rhythm and the likelihood of participating in the stock market. Consequently, the results are still robust after changing the measurements of key variables, which enhances the empirical evidence supporting the hypothesized relationships. For brevity purposes, we report the details of robustness check in Appendix B.

\section{Discussion}

The first goal of the current study was to explore the effects of circadian rhythm on financial behaviour, including revolving credit card payments and stock market participation as well as the possible mechanisms (i.e., channels) through which theses effect take place. In particular, we aim to get a better understanding of the links between (1) circadian rhythm, time preference, and delinquent credit card payments, as well as the relationships between (2) circadian rhythm, financial risk preference, and stock market participation. In fact, we investigated how morningness is related to the likelihood of delinquent credit card payments, and whether time preference is one channel through which morningness indirectly affects the likelihood of delinquent credit card payment. In addition, we test how income moderates the mediating relationship between morningness, time preference, and delinquent credit card payments. Partially, as expected, the survey results empirically demonstrate that morningness is negatively associated with the likelihood of delinquent credit card payments. Time preference is one of the channels through which morningness influences the likelihood of incomplete credit card debt. Moreover, this indirect relationship is identified to be significant if and only if individuals have a median or high level of monthly income.

The second goal of this paper was to examine the effects of circadian rhythm on stock market participation and explore the plausible channels through which these effects occur. Specifically, we examine how morningness is associated with the likelihood of stock market participation, and whether financial risk preference is one channel through which morningness indirectly influences the likelihood of stock market participation. Additionally, we test whether income moderates the mediating relationship between morningness, financial risk preference, and delinquent credit card debt. The results confirm that morningness only influences the likelihood of participating in the stock market through financial risk preference. An additional finding is that the results indicate that morningness is positively associated with financial risk preference, which contradicts the previous studies that reported morningness is inversely related to risk taking $[25,137,138]$. Finally, neither morningness is directly associated with stock market participation or income moderates the indirect relationship between morningness, financial risk preference, and participation in the stock market.

These findings have some important theoretical and practical implications.

\subsection{Theoretical Implications}

In general, we extend the literature by adding the knowledge that circadian typologies can influence financial behaviour through individual economic differences (i.e., time preference and financial risk preference), and we provide an informative picture regarding the relationships between them based on inferential statistics.

We contribute to this stream of literature by recognizing that morning-type people can inhibit the probability of delinquent credit cards and time preference represents one of the channels through which this occurs. The research expands the present understanding of the functional effect of morningness-eveningness [1] by theoretically and empirically suggesting the relationship between morningness and the likelihood of delinquent credit card payments. We propose and find a direct negative association between morningness and delinquent credit card payment, which makes it clear that the morning chronotype significantly suppresses the likelihood of revolving credit card debt. One possible mechanism for this association is self-control because morningness prompts individuals to be more self-regulated [65], which is negatively associated with non-payment of credit cards and the financial burdens of debt [139]. Another possible mechanism for this link could be through a 
character inventory. Morning larks are more prone to being persistent [140], conscientious [141], and proactive [33] as compared with evening owls. In particular, proactive people tend to examine, expect, and diminish the effects of potential problems in the future, avoiding them as much as possible [62,63]. As a result, these people are more likely to avoid delinquent credit card debt. We also hypothesize and the results reveal that time preference partially mediates the relationship between morningness and delinquent credit card payments, thus replicating the association between morning chronotype and time perspective [142,143], and expanding upon the initial work by using a Chinese sample. Morning larks appear to focus on future target attainment and suspend gratification [65]. The study also extends the knowledge regarding the effect of morning-type on various behaviours that were mainly in the health and education fields [1,144-148] to the financial field. An additional highlight is that the mediating role of time preference in the morningness-delinquent credit card payment relationship goes beyond the effects of the demographic predictors that we control for in the analyses. Furthermore, by integrating insights from theories on time preference and credit card borrowing [24,149-151], and from theories on income and credit card debt [27], we propose and investigate how income moderates the mediating role of time preference on the morningness-delinquent credit card payments relationship. The findings show that time preference induced by a morning-oriented rhythm result in less likelihood of revolving credit card debt at mean and low levels of income. Specifically, the possible reason for the results regarding users of credit cards with low and mean levels of income is that they are concerned about the level of their financial debt, given the compounding rate of credit card debt. Because their financial situation is vulnerable to high interest rates, which will increase based on the amount of debt [19], another concern of people with low and mean levels of income may be their personal credit over the long term. Given the evidence that income is positively associated with credit card balances at average and low levels of income [27], an increase in income for these groups of people may result in higher credit-card debt. Consequently, to maintain the utility of personal credit, future-oriented people with low and average levels of income will try their best to avoid any default-related behaviour. However, individuals with a high level of income appear to be much less likely to be in a weak position such that their financial situation would be profoundly harmed due to unpaid credit card debt. For that reason, for this group of people, time preference is not a mediator for the likelihood of delinquent credit card payments.

Another important contribution of this study is to identify that circadian rhythms can exert influence on the probability of owning equity through financial risk preference. We advance the current understanding of the effect of morningness on risk behaviour related to investment matters by empirically investigates whether and how morningness affect financial risk taking and in turn influences stock market participation. We also offer possible explanations from multiple perspectives for why morning larks are prone to more risk taking, which can lead to the sequential outcome of owning equity. First, contrary to expectations [25], we find that morningness people are more likely to engage in financial risk taking. Since genetic factors [152] can explain a large amount of the variance of circadian typologies, and biological and physiological factors [153,154] are significant predictors of them, we are able to provide a plausible explanation. In the literature, Kandasamy et al. [155] argued that acute cortisol lift-up is associated with increased physical arousal [156], enhanced memory recall [157], higher frequency of interaction with dopaminergic paths in the brain, promoted learning, induced behaviour, and sensation seeking. In addition, Cueva et al. [158] clarified that cortisol and testosterone lead to increased financial risk preference. Therefore, the possible channel could be cortisol. Empirical research has suggested that the mean cortisol level of morning-type people is larger than the mean cortisol level of evening-type ones [159]. When compared with evening owls, morning larks may have a higher level of cortisol in their first hour after waking [160]. In addition, morningness people have moderately greater cortisol concentrations after waking than eveningness individuals [161,162]. Because cortisol tends to directly increase risk taking, it could shed light on the positive association between morning-types and financial risk preference. Another possible channel could be testosterone, which could induce people to be more optimistic about risk regarding price changes in the financial 
market [158], although Randler et al. [163], in the first place, put forward that testosterone is positively associated with evening-types in young adults between 20 and 30 years of age. Given this contrasting evidence, we do not deny that testosterone may also contribute to the higher level of risk taking among morning-oriented people, as our sample is quite heterogeneous from a demographic perspective. For example, our sample spans a larger age range (18 to 44 years old) and is a mixed gender sample rather than only males. A possible third channel is a happy mood. On the one hand, when compared with evening owls, morning larks have higher levels of positive mood in both the young and old age groups, which make them happier [77]. When evening owls force themselves to get up early and produce in the daytime, it leads to some extent of sleep loss and emotional stress and in turn they are less happy. On the other hand, being happy is positively associated with a greater level of financial risk taking [164]. Positive emotional states, such as excitement and happiness, prompt individuals to take risks and to have more confidence in their abilities when making financial decisions [165]. Second, with regard to the finding that financial risk preference fully mediates the relationship between morning-type people and owning equity as a behavioural consequence, it is straightforward to argue that financial risk preference is a unique channel. Empirical research in the risk attitude domain suggests that risk tolerance is positively associated with risky behaviour, including holding equity, which might be useful in many applications with a variety of different datasets [166]. Risk attitudes can explain the variance in risky behaviour, and the willingness to take risks in financial matters predicts the probability of owning stock much better than risk predictors do in other contexts [26]. By integrating the evidence from the literature described above, we articulate the importance of the financial-risk taking process mechanism that is intrinsically embedded in the connection between morning-types and the probability of owning stock.

Empirical studies in the behavioural finance domain have focused on investigating the antecedents and outcomes of interest, in this case in terms of investment behaviour. Morningness-eveningness denotes biological rhythms, which is a temporality of humanity that cannot be backward, but only as an elemental level [23]. We contribute by linking circadian rhythms with risk preference and time preference. Apprehending individuals' decision-making both under risk and over time represents two fundamental domains of economic analysis [28] and policy design [167]. However, they are distinctive conceptions [136,168]. Prospect theory [169] takes risk attitude as a free parameter, while Zimbardo and Boyd [170] defined time preference as a temporal category. It is therefore of benefit to explore their process mechanisms. Although cross-sectional research based on regressions have limitation to clarify causality [171], we still have provided some reasonable explanation regarding the path from the circadian typologies to risk and time preferences in the above two paragraphs. Furthermore, we extend the empirical literature by identifying the mediating mechanism of risk and time preference between circadian rhythms and financial behaviour and the moderation mechanism of income in the indirect relationship between morningness and delinquent credit card payments through time preference. As such, we add fine-grained knowledge about whether, how, and when circadian rhythms influence financial behaviour in a sequential process.

\subsection{Practical Implications}

Given the evidence that morning larks are less likely to have revolving credit balances when compared with evening owls, morningness is indirectly and positively associated with the likelihood of participation in the stock market. From a financial perspective, evening-types do not seem to be in an advantageous position. Because in the short term, having delinquent credit card debt lead to higher interest rates, financial penalties, and higher outstanding balances [20], and in the long-term, such behaviour harms financial well-being. In addition, non-participation in the stock market over the long term is costly because the stock premium is more likely to accumulate long-term benefits in personal savings, which in turn produce personal well-being. Therefore, we have following practical implication. For individuals, evening-oriented people should prevent from adopting poor loan payment habits in order to avoid unpaid credit debt, and they should pay loans back on time. In addition, empirical 
evidence indicates that evening owls might shift their sleep-wake time schedule to be closer to morning larks. Although the circadian chronotypes are time stable, this does not mean this characteristic is unchangeable. As a result, we anticipate that evening owls could have longer daytime to process information and deal with things, and become more proactive, more conscientious, as well as improve their mood, which may contribute a higher likelihood of participation in the stock market. In addition, financial institutions can assess the chronotypes of customers as predictors of their behaviour. For example, financial institutions could remind evening-oriented customers about the due dates of their loan payment slightly more often but still in a soft manner, such as through email or app notifications. Furthermore, financial organizations could recommend customized portfolio according to customer' circadian type. For example, financial risk involved with the suggested financial products for morning larks could be slightly higher than those proposed for evening owls.

\section{Conclusions}

In summary, to further understanding of the influence of circadian rhythms on specific financial behaviour (e.g., delinquent credit card payments and stock market participation), we integrated and examined the role of time perspective and risk preference in a sequential process. We conducted regressions and path analysis based on an online survey sample representing the group of people who have been working for three to eight years in China. The findings show that compared to evening-type and neither-type individuals, morning larks are much less likely to have revolving credit card debt and one of the channels is the individual's time perspective. However, time preference only partially mediates the relationship between morning chronotype and the probability of having revolving credit card debt when individual' income level is at average and low, for the path from time preference to delinquent credit card payments.

Some limitations of this paper warrant mention. First, the sample included workers who have been working for 3 to 8 years and consequently, future studies could benefit from using a wider age spectrum. Second, the use of other measures of circadian rhythm, such as rMEQ [172] and MESSi [35] could potentially overcome the issue of unevenly distributed chronotypes in our Chinese samples. Third, it would be interesting to examine cultural and environmental differences with respect to our results and findings, such as in an individualism-oriented country and using culturally modified cut-off criteria of chronotypes, as proposed by Kerkhof [173] and Caci et al. [174], in future studies.

The present study helps to clarify the underlying mechanism and the condition in the link between circadian typologies and revolving credit card debt. Another novel finding is that risk preference fully mediates the relationship between morningness and the probability of owning equity. Therefore, the current study is also helpful to elucidate the unique channel and mechanism through which being morning-oriented exerts an influence on stock market participation. Furthermore, the results could be a valuable tool for financial professionals who could consider circadian rhythms when developing and introducing financial products or financial services to morning-type, intermediate-type, and evening-type populations. Future research could extend by studying the relationship between chronotypes, preference constructs, and financial behaviour by adding sampling frames, such as including aging cohorts, general populations in other countries. In addition, longitudinal studies are particularly of use to validate the proposed relationships. A further step could be to verify causal relationships among these variables by implementing behavioural experiments.

Author Contributions: Conceptualization, D.W. and F.M.; Methodology, D.W.; Software usage, D.W.; Validation, F.M. and E.-T.C.; Formal analysis, D.W.; Investigation and resources, D.W.; Original Draft Preparation, D.W.; Review and Editing, D.W., F.M. and E.-T.C.; Supervision, F.M. and E.-T.C.

Funding: This research received no external funding.

Conflicts of Interest: The authors declare no conflict of interest. 


\section{Appendix A}

The questionnaire of this paper

Research Title: Chronotype, risk and time preference, and financial behaviour

Participant information sheet (English version of questionnaire)

ERGO-number 26671

Please read this information carefully before deciding to take part in this research.

What is the research about?

This research is going to investigate how circadian typology (morningness or eveningness) affect financial behaviour, such incomplete credit card payment and stock market participation. Morningness refer to ones who are mentally and physically active during the morning hours while eveningness are ones who are more alert at night. We expect risk preference and time preference are able to bridge circadian typology and financial behaviour.

What will happen to me if I take part?

Participation will fill one questionnaire. It may take you 10 to $15 \mathrm{~min}$ to complete, including approximately 28 questions. Please make sure that you have sufficient time to finish if you are willing to joining. Your participation is very important because you will be profoundly contributing to this research.

Screening and eligibility?

If you have been working for 3 to 8 years and your age is +18 years old, you are eligible to take part in the research.

Will my participation be confidential and in safety?

There will be no risk in taking this survey. Your answers and personal information will be confidential. Your name and contact details will not be shown as it is not required to provide your name. Only the aggregate statistical data will be presented in this research, in terms of a paper in the future. Data and results will be stored properly according to the Data Protection Act and saved in a locked cabinet or encrypted file in a password-protected computer.

What happens if you change your mind?

You may withdraw your consent and participating in the study at any time. You will not be penalized for this.

Participants may wish to contact:

The researcher, Di Wang (dw2n13@soton.ac.uk).

Yes, I am willing to joining this survey.

No, I do not want to join

Circadian Preference (Morningness or Eveningness)

Please check the response for each item that best describes you.

1.1. Considering only your own "feeling best" rhythm, at what time would you get up if you were entirely free to plan your day?

5:00-6:30 a.m. (5)

6:30-7:45 a.m. (4)

7:45-9:45 a.m. (3)

9:45-11:00 a.m. (2)

11:00 a.m.-12:00 (noon) (1)

1.2. Considering your only "feeling best" rhythm, at what time would you go to bed if you were entirely free to plan your evening? 
8:00-9:00 p.m. (5)

9:00-10:15 p.m. (4)

10:15 p.m.-12:30 a.m. (3)

12:30-1:45 a.m. (2)

1:45-3:00 a.m. (1)

1.3. Assuming normal circumstance, how easy do you find getting up in the morning? (Check one.)

Not at all easy (1)

Slightly easy (2)

Fairly easy (3)

Very easy (4)

1.4. How alert do you feel during the first half hour after having awakened in the morning? (Check one.)

Not at all alert (1)

Slightly alert (2)

Fairly alert (3)

Very alert (4)

1.5. During the first half hour after having awakened in the morning. How tired do you feel? (Check one.)

Very tired (1)

Fairly tired (2)

Fairly refreshed (3)

Very refreshed (4)

1.6. You have decided to engage in some physical exercise. A friend suggests that you do this one hour twice a week and the best time for him is 7:00-8:00 a.m. Bearing in mind nothing else but your own "feeling best" rhythm, how do you think you would perform?

Would be in good form (4)

Would be in reasonable form (3)

Would find it difficult (2)

Would find it very difficult (1)

1.7. At what time in the evening do you feel tired and, as a result, in need of sleep?

8:00-9:00 p.m. (5)

9:00-10:15 p.m. (4)

10:15 p.m.-12:30 a.m. (3)

12:30-1:45 a.m. (2)

1:45-3:00 a.m. (1)

1.8. You wish to be at your peak performance for a test which you know is going to be mentally exhausting and lasting for two hours. You are entirely free to plan your day, and considering only your own "feeling best" rhythm, which one of the four testing times would you choose?

8:00-10:00 a.m. (4)

11:00 a.m.-1:00 p.m. (3)

3:00-5:00 p.m. (2)

7:00-9:00 p.m. (1)

1.9. One hears about "morning" and "evening" types of people. Which ONE of these types do you consider yourself to be? 
Definitely a morning type (4)

More a morning than an evening type (3)

More an evening than a morning type (2)

Definitely an evening type (1)

1.10. When would you prefer to rise (provided you have a full day's work $-8 \mathrm{~h}$ ) if you were totally free to arrange your time?

Before 6:30 a.m. (4)

6:30-7:30 a.m. (3)

7:30-8:30 a.m. (2)

8:30 a.m. or later (1)

1.11. If you always had to rise at 6:00 a.m., what do you think it would be like?

Very difficult and unpleasant (1)

Rather difficult and unpleasant (2)

A little unpleasant but no great problem (3)

Easy and not unpleasant (4)

1.12. How long a time does it usually take before you "recover your senses" in the morning after rising from a night's sleep?

$0-10 \min (4)$

$11-20 \min (3)$

21-40 $\min (2)$

More than $40 \min (1)$

1.13. Please indicate to what extent you are a morning or evening active individual

Pronounced morning active (morning alert and evening tired) (4)

To some extent, morning active (3)

To some extent, evening active (2)

Pronounced evening active (morning tired and evening alert) (1)

\section{Demographic information}

2.1. What is your age?

$18-29(1)$

30-44 (2)

$45-54(3)$

2.2. What is your gender?

Female (0)

Male (1)

2.3. Marital status:

Others (0)

Married (1) 


\subsection{Highest Level of Education Attained}

Less than High School (1)

High school graduate (2)

Some college (3)

Bachelor degree (4)

Master degree (5)

$\mathrm{PhD}(6)$

2.5. What is your monthly income in Chinese RMB?

Less than RMB3000 (1)

RMB3000 to RMB5000 (2)

RMB5000 to RMB7500 (3)

RMB7500 to RMB10,000 (4)

RMB10,000 to RMB20,000 (5)

More than RMB20,000 (6)

2.6. Generally speaking, would you say that most people can be trusted, or that you cannot be too careful in dealing with people?

Strongly disagree (1)

Disagree (2)

Somewhat disagree (3)

Neither agree nor disagree (4)

Somewhat agree (5)

Agree (6)

Strongly agree (7)

2.7. Have you invested in the stock market?

No (0)

Yes (1)

2.8. How do you see yourself? Are you generally a person who is fully prepared to take risks or do you try to avoid taking risks? Please tick a choice on the scale, where the value 0 means 'not at all willing to take risks', and the value 10 means 'very willing to take risks'

$$
0
$$

1

3

4

5

6

2.9. How do you see yourself? Are you generally a person who is fully prepared to take financial risks or do you try to avoid taking financial risks? Please tick a choice on the scale, where the value 0 means 'not at all willing to take financial risks', and the value 10 means 'very willing to take financial risks' 
2.10. Please indicate below the option that best describes your payments on credit cards.

I do not use credit cards for payments (0)

Always pays off monthly (1)

Generally pays off monthly (2)

Occasionally pays off monthly (3)

Seldom pays off, but tries to pay down (4)

Generally pays minimum each month (5)

\section{Time preference}

3.1. When you are driving a car, how likely is it that you are wearing your seatbelt?

Never (1)

Sometimes (2)

About half the time (3)

Most of the time (4)

Always (5)

3.2. How often do you smoke cigarettes?

Never (5)

Sometimes (4)

About half the time (3)

Most of the time (2)

Always (1)

3.3. How often do you consume alcoholic beverages?

Never (5)

Sometimes (4)

About half the time (3)

Most of the time (2)

Always (1)

3.4. How often do you use nutrition labels to select the foods you buy?

Never (1)

Sometimes (2)

About half the time (3)

Most of the time (4) 
Always (5)

3.5. How often do you engage in strenuous physical exercise?

Never (1)

Sometimes (2)

About half the time (3)

Most of the time (4)

Always (5)

3.6. How often have you engaged in unprotected sex during the last year?

Never (5)

Sometimes (4)

About half the time (3)

Most of the time (2)

Always (1)

3.7. How often do you choose foods for the purpose of creating a diet that will reduce your chances of having a diet-related illness in the future?

Never (1)

Sometimes (2)

About half the time (3)

Most of the time (4)

Always (5)

\section{Appendix B}

\section{Robustness Check}

We changed the dichotomously measured morningness in the benchmark analysis to a continuum scale because based on the idea proposed by Chelminski et al. [135] that using a continuum scale for morningness-eveningness could provide richer information regarding the hypothesized relationships. We also used a different single self-reported question, as proposed by Dohmen et al. [26], to measure risk preference, and generate an all-around factor to predict risky behaviour. In addition, we added both risk and time preference measures in all settings of regressions and path analyses, as risk and time are intertwined. It would be problematic to isolate risk attitude when examining the effect of time preference on certain behaviour [136], as uncontrolled risk can create present-biased choices or behaviour. By changing the measurements of the interested variables and increasing bootstrap sample size from 5000 to 50,000 , we intend to verify the robustness of the results.

The continuum form of morningness-eveningness (Circadian rhythm) ranges from 15 to 51, where a higher score indicates greater morning orientation. General risk preference is a single indicator with a higher score presenting a higher level of risk taking, ranging from 1 to 11 .

We conducted a robustness check on hypotheses $(\mathrm{H} 1, \mathrm{H} 2, \mathrm{H} 3, \mathrm{H} 4, \mathrm{H} 6)$, because these hypotheses were supported by the benchmark results. First, we tested the link between circadian rhythm and revolving credit card debt.

The results recorded in Table A1 indicate that circadian rhythm is negatively associated with the possibility of delinquent credit card payments $(b=-0.012, \mathrm{SE}=0.003, \mathrm{z}=-3.37, p<0.01)$, which supports Hypothesis 1. 
Table A1. The effect of circadian rhythm on likelihood of delinquent credit card payments in logistic regression.

\begin{tabular}{|c|c|c|c|c|}
\hline \multirow{2}{*}{$\begin{array}{c}\text { Dependent Variable: Delinquent Credit Card Payment } \\
\text { Variables }\end{array}$} & \multicolumn{4}{|c|}{ Logistic Regression } \\
\hline & Average Marginal Effect & $\mathrm{SE}$ & z-Statistic & $p$-Value \\
\hline \multicolumn{5}{|l|}{ Main variables } \\
\hline Circadian rhythm & $-0.012^{* * *}$ & 0.003 & -3.47 & 0.001 \\
\hline \multicolumn{5}{|l|}{ Control variables } \\
\hline Age & 0.005 & 0.048 & 0.10 & 0.922 \\
\hline Male & -0.030 & 0.048 & -0.63 & 0.530 \\
\hline Married & 0.046 & 0.054 & 0.85 & 0.394 \\
\hline Education & -0.026 & 0.044 & -0.58 & 0.565 \\
\hline Monthly income & 0.019 & 0.024 & 0.80 & 0.425 \\
\hline Time preference & $-0.018 * *$ & 0.008 & -2.15 & 0.032 \\
\hline General risk preference & 0.021 & 0.014 & 1.51 & 0.132 \\
\hline Log pseudolikelihood & -278.827 & & & \\
\hline Pseudo R2 & 0.045 & & & \\
\hline Number of observations & 455 & & & \\
\hline
\end{tabular}

Second, we tested whether time preference mediates the relationship between circadian rhythm and delinquent credit card debt. Table A2 conveys the results (bootstrapping coefficient of indirect effect $=-0.107$, bootstrapping SE $=0.006,95 \% C=[-0.024,-0.001])$, which supports Hypothesis 2 .

Table A2. The mediating effect of time preference on the relationship between circadian rhythm and delinquent credit card payments.

\begin{tabular}{|c|c|c|c|c|c|c|}
\hline \multirow[b]{2}{*}{ Variables } & \multicolumn{3}{|c|}{ Time Preference } & \multicolumn{3}{|c|}{ Delinquent Credit Card Payments } \\
\hline & Coefficient & SE & $\mathbf{t}$ & Coefficient & SE & $\mathbf{z}$ \\
\hline Constant & $15.630^{* * *}$ & 1.522 & 10.271 & 2.716 & 1.165 & 2.331 \\
\hline Circadian rhythm & $0.126^{* * *}$ & 0.024 & 5.274 & $-0.055^{* * *}$ & 0.017 & -3.283 \\
\hline Age & $0.632 * *$ & 0.272 & 2.325 & 0.023 & 0.222 & 0.100 \\
\hline Male & $-1.030 * * *$ & 0.279 & -3.693 & -0.141 & 0.222 & -0.637 \\
\hline Married & -0.381 & 0.334 & -1.141 & 0.218 & 0.257 & 0.848 \\
\hline Education & $0.968^{* * *}$ & 0.309 & 3.130 & -0.121 & 0.199 & -0.605 \\
\hline Monthly income & -0.130 & 0.166 & -0.788 & 0.089 & 0.106 & 0.838 \\
\hline General risk preference & 0.183 & 0.088 & 2.080 & 0.101 & 0.065 & 1.551 \\
\hline Time preference & & & & $-0.085 * *$ & 0.038 & -2.239 \\
\hline R2 & 0.168 & & & & & \\
\hline Pseudo R2 & & & & 0.045 & & \\
\hline Number of observations & 455 & & & 455 & & \\
\hline Mediator Time preference & Bootstrapping effect & & Boot SE & & $95 \% \mathrm{CI}$ & LL, UL) \\
\hline Indirect effect & -0.107 & & 0.006 & & -0.023 & -0.001 \\
\hline
\end{tabular}

Third, we set out to verify whether income moderates the time preference-delinquent credit card debt relationship, and whether the indirect effect of circadian rhythm on delinquent credit debt payments through time perspective, is moderated by monthly income, such that an indirect effect exists for those whose income is at low to average level. Table A3 reports the corresponding results, which supports Hypothesis 3 (The coefficient of interaction item monthly income $\times$ time preference $=0.065$, $\mathrm{SE}=0.028, p<0.05$ ) and Hypothesis 4 (Index of moderated mediation $=0.008$, Boot SE $=0.004$, $95 \% \mathrm{CI}=[0.001,0.018])$. 
Table A3. The conditional indirect effect of circadian rhythm on delinquent credit card payments.

\begin{tabular}{|c|c|c|c|c|c|c|}
\hline \multirow[b]{2}{*}{ Variables } & \multicolumn{3}{|c|}{ Time Preference } & \multicolumn{3}{|c|}{ Delinquent Credit Card Payments } \\
\hline & Coefficient & SE & $\mathbf{t}$ & Coefficient & SE & $\mathbf{z}$ \\
\hline Constant & $-9.431^{* * *}$ & 1.509 & -6.251 & $0.687^{* * *}$ & 1.151 & 0.597 \\
\hline Male & $-1.053^{* * *}$ & 0.281 & -3.747 & -0168 & 0.223 & -0.756 \\
\hline Married & -0.429 & 0.326 & -1.317 & 0.186 & 0.260 & 0.716 \\
\hline Education & $0.881 * * *$ & 0.276 & 3.195 & -0.127 & 0.200 & -0.633 \\
\hline Circadian rhythm & $0.127^{* * *}$ & 0.024 & 5.316 & $-0.057^{* * *}$ & 0.017 & -3.372 \\
\hline Time preference & & & & $-0.107^{* * *}$ & 0.040 & -2.713 \\
\hline $\begin{array}{l}\text { Monthly income } \times \text { Time } \\
\text { preference }\end{array}$ & & & & $0.065^{* *}$ & 0.028 & 2.343 \\
\hline R2 & 0.166 & & & & & \\
\hline Pseudo R2 & & & & 0.054 & & \\
\hline Number of observations & 455 & & & 455 & & \\
\hline Index of moderated mediation & & & & & & \\
\hline Mediator & Index & Boot SE & & & $95 \% \mathrm{C}$ & L, UL) \\
\hline Time preference & 0.008 & 0.004 & & & 0.001 & 0.018 \\
\hline
\end{tabular}

Finally, we examined whether financial risk preference mediates the relationship between circadian rhythm and the likelihood of investments in the stock market. Table A4 shows the results (bootstrapping coefficient of indirect effect $=0.010$, bootstrapping $\mathrm{SE}=0.006,95 \% \mathrm{CI}=[0.0002,0.022]$ ) that support Hypothesis 6.

Table A4. The mediating effect of general risk preference on the relationship between circadian rhythm and stock market participation.

\begin{tabular}{|c|c|c|c|c|c|c|}
\hline \multirow[b]{2}{*}{ Variables } & \multicolumn{3}{|c|}{ General Risk Preference } & \multicolumn{3}{|c|}{ Stock Market Participation } \\
\hline & Coefficient & SE & $t$ & Coefficient & SE & $\mathbf{z}$ \\
\hline Constant & $4.534 * * *$ & 0.924 & 4.907 & $-5.454^{* * *}$ & 1.293 & -4.218 \\
\hline Age & -0.244 & 0.171 & -1.426 & 0.112 & 0.238 & 0.472 \\
\hline Male & $0.732^{* * *}$ & 0.166 & 4.412 & $0.524^{* *}$ & 0.239 & 2.196 \\
\hline Married & 0.082 & 0.201 & 0.410 & $0.511 * *$ & 0.260 & 1.964 \\
\hline Education & -0.213 & 0.144 & -1.481 & $0.659^{* * *}$ & 0.218 & 3.030 \\
\hline General risk preference & & & & $0.380^{* * *}$ & 0.068 & 5.601 \\
\hline R2 & 0.126 & & & & & \\
\hline Pseudo R2 & & & & 0.125 & & \\
\hline Number of observations & 455 & & & 455 & & \\
\hline Mediator General risk preference & Bootstrapping effect & & Boot SE & & $95 \%$ & (UL) \\
\hline Indirect effect & 0.010 & & 0.006 & & 0.0002 & 0.022 \\
\hline
\end{tabular}

To summarize, after changing the measures of morningness-eveningness, and the measure of risk preference, the results are robust and support the findings in the benchmark analysis.

\section{References}

1. Piffer, D.; Ponzi, D.; Sapienza, P.; Zingales, L.; Maestripieri, D. Morningness-eveningness and intelligence among high-achieving US students: Night owls have higher GMAT scores than early morning types in a top-ranked MBA program. Intelligence 2014, 47, 107-112. [CrossRef]

2. Nelson, R.J. An Introduction to Behavioral Endocrinology, 4th ed.; Sinauer: Sunderland, MA, USA, 2011.

3. Andretic, R.; Franken, P.; Tafti, M. Genetics of sleep. Annu. Rev. Genet. 2008, 42, 361-388. [CrossRef] [PubMed] 
4. Baehr, E.K.; Revelle, W.; Eastman, C.I. Individual differences in the phase and amplitude of the human circadian temperature rhythm: With an emphasis on morningness-eveningness. J. Sleep Res. 2000, 9, 117-127. [CrossRef] [PubMed]

5. Kerkhof, G.A.; Van Dongen, H.P. Morning-type and evening-type individuals differ in the phase position of their endogenous circadian oscillator. Neurosci. Lett. 1996, 218, 153-156. [CrossRef]

6. Franken, P.; Dijk, D.J. Circadian clock genes and sleep homeostasis. Eur. J. Neurosci. 2009, 29, $1820-1829$. [CrossRef] [PubMed]

7. Natale, V.; Cicogna, P. Morningness-eveningness dimension: Is it really a continuum? Personal. Individ. Differ. 2002, 32, 809-816. [CrossRef]

8. Horne, J.A.; Ostberg, O. A self-assessment questionnaire to determine morningness-eveningness in human circadian rhythms. Int. J. Chronobiol. 1976, 4, 97-110. [PubMed]

9. McLaughlin, C.; Bowman, M.L.; Bradley, C.L.; Mistlberger, R.E. A Prospective Study of Seasonal Variation in Shift-Work Tolerance. Chronobiol. Int. 2008, 25, 455-470. [CrossRef] [PubMed]

10. Waterhouse, J.; Edwards, B.; Nevill, A.; Carvalho, S.; Atkinson, G.; Buckley, P.; Ramsay, R. Identifying some determinants of "jet lag" and its symptoms: A study of athletes and other travellers. Br. J. Sports Med. 2002, 36, 54-60. [CrossRef] [PubMed]

11. Flower, D.J.; Irvine, D.; Folkard, S. Perception and predictability of travel fatigue after long-haul flights: A retrospective study. Aviat. Space Environ. Med. 2003, 74, 173-179. [PubMed]

12. Colquhoun, W.P. Circadian variations in mental efficiency. In Biological Rhythms and Human Performance; Academic Press: London, UK, 1971; pp. 39-107.

13. Sternberg, R.J.; Zhang, L.F. Perspectives on Thinking, Learning, and Cognitive Styles; Routledge: New York, NY, USA, 2014.

14. Antúnez, J.M.; Navarro, J.F.; Adan, A. Morningness-eveningness and personality characteristics of young healthy adults. Personal. Individ. Differ. 2014, 68, 136-142. [CrossRef]

15. Martin, J.S.; Hébert, M.; Ledoux, É.; Gaudreault, M.; Laberge, L. Relationship of chronotype to sleep, light exposure, and work-related fatigue in student workers. Chronobiol. Int. 2012, 29, 295-304. [CrossRef] [PubMed]

16. Levandovski, R.; Dantas, G.; Fernandes, L.C.; Caumo, W.; Torres, I.; Roenneberg, T.; Allebrandt, K.V. Depression scores associate with chronotype and social jetlag in a rural population. Chronobiol. Int. 2011, 28, 771-778. [CrossRef] [PubMed]

17. Achilles, G.M. Individual differences in Morningness-eveningness and patterns of psychological functioning, social adaptation and family stress. Diss. Abstr. Int. Sect. B Sci. Eng. 2003, 64, 2954.

18. Kruger, P.S. Wellbeing-The five essential elements. Appl. Res. Qual. Life 2011, 6, 325-328. [CrossRef]

19. Kim, H.; DeVaney, S.A. The determinants of outstanding balances among credit card revolvers. J. Financ. Couns. Plan. 2001, 12, 67-78.

20. Elliehausen, G.; Christopher, L.E.; Staten, M.E. The impact of credit counseling on subsequent borrower behaviour. J. Consum. Aff. 2007, 41, 1-28. [CrossRef]

21. Almenberg, J.; Dreber, A. Gender, stock market participation and financial literacy. Econ. Lett. 2015, 137, 140-142. [CrossRef]

22. Díaz-Morales, J.F.; Sánchez-Lopez, M.P. Morningness-eveningness and anxiety among adults: A matter of sex/gender? Personal. Individ. Differ. 2008, 44, 1391-1401. [CrossRef]

23. Stolarski, M.; Ledzińska, M.; Matthews, G. Morning is tomorrow, evening is today: Relationships between chronotype and time perspective. Boil. Rhythm. Res. 2013, 44, 181-196. [CrossRef]

24. Meier, S.; Sprenger, C. Present-biased preferences and credit card borrowing. Am. Econ. J. Appl. Econ. 2010, 2, 193-210. [CrossRef]

25. Wang, L.; Chartrand, T.L. Morningness-eveningness and risk taking. J. Psychol. 2015, 149, 394-411. [CrossRef] [PubMed]

26. Dohmen, T.; Falk, A.; Huffman, D.; Sunde, U.; Schupp, J.; Wagner, G.G. Individual risk attitudes: Measurement, determinants, and behavioral consequences. J. Eur. Econ. Assoc. 2011, 9, 522-550. [CrossRef]

27. Calem, P.S.; Mester, L.J. Consumer behavior and the stickiness of credit card interest rates. Am. Econ. Rev. 1995, 85, 1327-1336.

28. Tanaka, T.; Camerer, C.F.; Nguyen, Q. Risk and Time Preferences: Linking Experimental and Household Survey Data from Vietnam. Am. Econ. Rev. 2010, 100, 557-571. [CrossRef] 
29. Smith, C.S.; Reilly, C.; Midkiff, K. Evaluation of three circadian rhythm questionnaires with suggestions for an improved measure of morningness. J. Appl. Psychol. 1989, 74, 728-738. [CrossRef] [PubMed]

30. Finke, M.S.; Huston, S.J. Time preference and the importance of saving for retirement. J. Econ. Behav. Organ. 2013, 89, 23-34. [CrossRef]

31. Cavallera, G.M.; Giudici, S. Morningness and eveningness personality: A survey in literature from 1995 up till 2006. Personal. Individ. Differ. 2008, 44,3-21. [CrossRef]

32. Adan, A.; Archer, S.N.; Hidalgo, M.P.; Di Milia, L.; Natale, V.; Randler, C. Circadian typology: A comprehensive review. Chronobiol. Int. 2012, 29, 1153-1175. [CrossRef] [PubMed]

33. Randler, C. Proactive people are morning people. J. Appl. Soc. Psychol. 2009, 39, 2787-2797. [CrossRef]

34. Torsvall, L.; Åkerstedt, T. A diurnal type scale: Construction, consistency and validation in shift work. Scand. J. Work Environ. Health 1980, 6, 283-290. [CrossRef] [PubMed]

35. Randler, C.; Díaz-Morales, J.F.; Rahafar, A.; Vollmer, C. Morningness-eveningness and amplitude-development and validation of an improved composite scale to measure circadian preference and stability (MESSi). Chronobiol. Int. 2016, 33, 832-848. [CrossRef] [PubMed]

36. Faßl, C.; Quante, M.; Mariani, S.; Randler, C. Preliminary findings for the validity of the Morningness-Eveningness-Stability Scale improved (MESSi): Correlations with activity levels and personality. Chronobiol. Int. 2018, 1-8. [CrossRef] [PubMed]

37. Kim, S.J.; Lee, Y.J.; Kim, H.; Cho, I.H.; Lee, J.Y.; Cho, S.J. Age as a moderator of the association between depressive symptoms and morningness-eveningness. J. Psychosom. Res. 2010, 68, 159-164. [CrossRef] [PubMed]

38. Merikanto, I.; Kronholm, E.; Peltonen, M.; Laatikainen, T.; Lahti, T.; Partonen, T. Relation of chronotype to sleep complaints in the general Finnish population. Chronobiol. Int. 2010, 29, 311-317. [CrossRef] [PubMed]

39. Adan, A.; Natale, V. Gender differences in morningness-eveningness preference. Chronobiol. Int. 2002, 19, 709-720. [CrossRef] [PubMed]

40. Mongrain, V.; Paquet, J.; Dumont, M. Contribution of the photoperiod at birth to the association between season of birth and diurnal preference. Neurosci. Lett. 2006, 406, 113-116. [CrossRef] [PubMed]

41. Natale, V.; Di Milia, L. Season of birth and morningness: Comparison between the northern and southern hemispheres. Chronobiol. Int. 2011, 28, 727-730. [CrossRef] [PubMed]

42. Duffy, J.F.; Dijk, D.J.; Hall, E.F.; Czeisler, C.A. Relationship of endogenous circadian melatonin and temperature rhythms to self-reported preference for morning or evening activity in young and older people. J. Investig. Med. 1999, 47, 141-150. [PubMed]

43. Katzenberg, D.; Young, T.; Finn, L.; Lin, L.; King, D.P.; Takahashi, J.S. A CLOCK polymorphism associated with human diurnal preference. Sleep 1998, 21, 569-576. [CrossRef] [PubMed]

44. Sõoru, E.; Hein, H.; Hazak, A. Why force owls to start work early? The work schedules of R\&D employees and sleep. TTU Econ. Res. Ser. 2017. Available online: www.tutecon.eu/index.php/TUTECON/article/ download/25/14 (accessed on 10 October 2018).

45. Carvalho, F.G.; de Souza, C.M.; Hidalgo, M.P.L. Work routines moderate the association between eveningness and poor psychological well-being. PLoS ONE 2018, 13, e0195078. [CrossRef] [PubMed]

46. Roberts, R.D.; Kyllonen, P.C. Morningness-eveningness and intelligence: Early to bed, early to rise will likely make you anything but wise! Personal. Individ. Differ. 1999, 27, 1123-1133. [CrossRef]

47. Natale, V.; Lorenzetti, R. Influences on Morningness-eveningness and time of day on narrative comprehension. Personal. Individ. Differ. 1997, 23, 685-690. [CrossRef]

48. Di Milia, L.; Muller, H. Does impression management impact the relationship between morningness-eveningness and self-rated sleepiness? Personal. Individ. Differ. 2012, 52, 702-706. [CrossRef]

49. Tankova, I.; Adan, A.; Buela-Casals, G. Circadian typology and individual differences. A review. Personal. Individ. Differ. 1994, 16, 671-684. [CrossRef]

50. Garman, E.T.; Forgue, R.E. Personal Finance, 12th ed.; Houghton Mifflin Company: Boston, NY, USA, 2012.

51. Hong, H.; Kubik, J.D.; Stein, J.C. Social interaction and stock-market participation. J. Financ. 2004, 59, 137-163. [CrossRef]

52. Guiso, L.; Jappelli, T. Awareness and stock market participation. Rev. Financ. 2005, 9, 537-567. [CrossRef]

53. Van Rooij, M.C.; Lusardi, A.; Alessie, R.J. Financial literacy and stock market participation. J. Financ. Econ. 2011, 101, 449-472. [CrossRef] 
54. Grinblatt, M.; Keloharju, M.; Linnainmaa, J. IQ and stock market participation. J. Financ. 2011, 66, $2121-2164$. [CrossRef]

55. Rosen, H.S.; Wu, S. Portfolio choice and health status. J. Financ. Econ. 2004, 72, 457-484. [CrossRef]

56. Bogan, V.L.; Fertig, A.R. Portfolio choice and mental health. Rev. Financ. 2013, 17, 955-992. [CrossRef]

57. Bogan, V. Stock market participation and the internet. J. Financ. Quant. Anal. 2008, 43, 191-211. [CrossRef]

58. Kirby, E.G.; Kirby, S.L. Improving task performance: The relationship between morningness and proactive thinking. J. Appl. Soc. Psychol. 2006, 36, 2715-2729. [CrossRef]

59. Parker, S.K.; Williams, H.M.; Turner, N. Modeling the antecedents of proactive behavior at work. J. Appl. Psychol. 2006, 91, 636-652. [CrossRef] [PubMed]

60. Seibert, S.E.; Crant, J.M.; Kraimer, M.L. Proactive personality and career success. J. Appl. Psychol. 1999, 84, 416-427. [CrossRef] [PubMed]

61. Kirby, E.G.; Kirby, S.L.; Lewis, M.A. A study of the effectiveness of training proactive thinking. J. Appl. Soc. Psychol. 2002, 32, 1538-1549. [CrossRef]

62. Aspinwall, L.G.; Hill, D.L.; Leaf, S.L. Prospects, pitfalls, and plans: A proactive perspective on social comparison activity. Eur. Rev. Soc. Psychol. 2002, 12, 267-298. [CrossRef]

63. Aspinwall, L.G.; Sechrist, G.B.; Jones, P.R. Expect the best and prepare for the worst: Anticipatory coping and preparations for $\mathrm{Y}_{2}$ K. Motiv. Emot. 2005, 29, 353-384. [CrossRef]

64. Hazembuller, A.; Lombardi, B.J.; Hogarth, J.M. Unlocking the risk-based pricing puzzle: Five keys to cutting credit card costs. Consum. Interests Annu. 2007, 53, 73-84.

65. Milfont, T.L.; Schwarzenthal, M. Explaining why larks are future-oriented and owls are present-oriented: Self-control mediates the chronotype-time perspective relationships. Chronobiol. Int. 2014, 31, 581-588. [CrossRef] [PubMed]

66. Benedetti, F.; Barbini, B.; Colombo, C.; Smeraldi, E. Chronotherapeutics in a psychiatric ward. Sleep Med. Rev. 2007, 11, 509-522. [CrossRef] [PubMed]

67. Fudenburg, D.; Levine, D.K. A dual-self model of impulse control. Am. Econ. Rev. 2006, 96, 1449-1476. [CrossRef]

68. Ando, A.; Modigliani, F. The 'life cycle' hypothesis of saving: Aggregate implication and tests. Am. Econ. Rev. 1963, 53, 55-84.

69. Bryant, W.K. The Economic Organization of the Households; Cambridge University Press: Cambridge, UK, 1990.

70. Vissing-Jorgensen, A. Towards an Explanation of Household Portfolio Choice Heterogeneity: Nonfinancial Income and Participation Cost Structures; National Bureau of Economic Research: Cambridge, MA, USA, 2002.

71. Bayer, P.J.; Bernheim, B.D.; Scholz, J.K. The effects of financial education in the workplace: Evidence from a survey of employers. Econ. Inq. 2009, 47, 605-624. [CrossRef]

72. Guiso, L.; Jappelli, T.; Terlizzese, D. Income risk, borrowing constraints, and portfolio choice. Am. Econ. Rev. 1996, 86, 158-172.

73. Heaton, J.; Lucas, D. Portfolio choice and asset prices: The importance of entrepreneurial risk. J. Financ. 2000, 55, 1163-1198. [CrossRef]

74. Guiso, L.; Sapienza, P.; Zingales, L. Trusting the stock market. J. Financ. 2008, 63, 2557-2600. [CrossRef]

75. Grinblatt, M.; Keloharju, M. How distance, language, and culture influence stockholdings and trades. J. Financ. 2001, 56, 1053-1073. [CrossRef]

76. Rao, Y.; Mei, L.; Zhu, R. Happiness and stock-market participation: Empirical evidence from China. J. Happiness Stud. 2016, 17, 271-293. [CrossRef]

77. Biss, R.K.; Hasher, L. Happy as a lark: Morning-type younger and older adults are higher in positive affect. Emotion 2012, 12, 437-441. [CrossRef] [PubMed]

78. Guven, C.; Hoxha, I. Rain or shine: Happiness and risk-taking. Q. Rev. Econ. Financ. 2015, 57, 1-10. [CrossRef]

79. Anderson, C.; Galinsky, A.D. Power, optimism, and risk-taking. Eur. J. Soc. Psychol. 2006, 36, 511-536. [CrossRef]

80. Yuen, K.S.; Lee, T.M. Could mood state affect risk-taking decisions? J. Affect. Disord. 2003, 75, 11-18. [CrossRef]

81. Edwards, P.J.; Roberts, I.G.; Clarke, M.J. Methods to increase response rates to postal questionnaires. Cochrane Database Syst. Rev. 2009, MR000008. [CrossRef]

82. Wjx Home Page. Available online: http:/ / www.wjx.cn (accessed on 1 August 2017).

83. Johnson, J.S. Improving online panel data usage in sales research. J. Pers. Sell. Sales Manag. 2016, 36, 74-85. [CrossRef] 
84. Hays, R.D.; Liu, H.; Kapteyn, A. Use of Internet panels to conduct surveys. Behav. Res. Methods 2015, 47, 685-690. [CrossRef] [PubMed]

85. Chen, D.; Cheng, C.Y.; Urpelainen, J. Support for renewable energy in China: A survey experiment with internet users. J. Clean. Prod. 2016, 112, 3750-3758. [CrossRef]

86. Liu, X.; Song, Y.; Wu, K.; Wang, J.; Li, D.; Long, Y. Understanding urban China with open data. Cities 2015, 47, 53-61. [CrossRef]

87. Burkill, S.; Copas, A.; Couper, M.P.; Clifton, S.; Prah, P.; Datta, J.; Erens, B. Using the web to collect data on sensitive behaviours: A study looking at mode effects on the British National Survey of Sexual Attitudes and Lifestyles. PLoS ONE 2016, 11, e0147983. [CrossRef] [PubMed]

88. Kreuter, F.; Presser, S.; Tourangeau, R. Social desirability bias in CATI, IVR, and web surveys: The effects of mode and question sensitivity. Public Opin. Q. 2008, 72, 847-865. [CrossRef]

89. Couper, M.P. New Developments in Survey Data Collection. Annu. Rev. Sociol. 2017, 43, 121-145. [CrossRef]

90. Callegaro, M.; DiSogra, C. Computing response metrics for online panels. Public Opin. Q. 2008, 72, 1008-1032. [CrossRef]

91. Biemer, P.P.; Lyberg, L.E. Introduction to Survey Quality; John Wiley \& Sons: Hoboken, NJ, USA, 2003.

92. Saunders, M.; Lewis, P.; Thornhill, A. Research Methods for Business Students, 6th ed.; Pearson: London, UK, 2012.

93. Meterko, M.; Restuccia, J.D.; Stolzmann, K.; Mohr, D.; Brennan, C.; Glasgow, J.; Kaboli, P. Response rates, nonresponse bias, and data quality: Results from a national survey of senior healthcare leaders. Public Opin. Q. 2015, 79, 130-144. [CrossRef]

94. Rindfuss, R.R.; Choe, M.K.; Tsuy, N.O.; Bumpass, L.L.; Tamaki, E. Do low survey response rates bias results? Evidence from Japan. Demogr. Res. 2015, 32, 797-828. [CrossRef]

95. Groves, R.M.; Peytcheva, E. The impact of nonresponse rates on nonresponse bias. Public Opin. Q. 2008, 72, 167-189. [CrossRef]

96. Smith, H.L. Double sample to minimize bias due to non-response in a mail survey. In Survey Methods: Applications to Longitudinal Studies, to Health, to Electoral Studies and to Studies in Developing Countries; Ruiz-Gazen, P.G.A., Haziza, D., Tille, Y., Eds.; Dunod: Paris, France, 2009; pp. 334-339.

97. Visser, P.S.; Krosnick, J.A.; Marquette, J.; Curtin, M. Mail surveys for election forecasting? An evaluation of the Columbus Dispatch poll. Public Opin. Q. 1996, 60, 181-227. [CrossRef]

98. Curtin, R.; Presser, S.; Singer, E. The effects of response rate changes on the index of consumer sentiment. Public Opin. Q. 2000, 64, 413-428. [CrossRef] [PubMed]

99. Keeter, S.; Kennedy, C.; Dimock, M.; Best, J.; Craighill, P. Gauging the impact of growing nonresponse on estimates from a national RDD telephone survey. Public Opin. Q. 2006, 70, 759-779. [CrossRef]

100. Holbrook, A.; Krosnick, J.A.; Pfent, A. The causes and consequences of response rates in surveys by the news media and government contractor survey research firms. In Advances in Telephone Survey Methodology; Lepkowski, J., Harris-Kojetin, B., Lavrakas, P.J., Tucker, C., de Leeuw, E., Link, M., Brick, M., Japec, L., Sangster, R.N., Eds.; Wiley: New York, NY, USA, 2007; pp. 499-528.

101. Worldometer's Home Page Regarding China Population (Live). 2017. Available online: http://www. worldometers.info/world-population/china-population/ (accessed on 7 December 2017).

102. Statista's Home Page Regarding Number of Internet Users in China from 2015 to 2022 (in Millions). 2017. Available online: https://www.statista.com/statistics/278417/number-of-internet-users-in-china/ (accessed on 7 December 2017).

103. World Development Indicator's Home Page Regarding Gross Enrolment Ratio, Tertiary, Both Sexes (\%). 2016. Available online: https:/ / data.worldbank.org/indicator/SE.TER.ENRR (accessed on 9 December 2017).

104. Paz, S.H.; Spritzer, K.L.; Morales, L.S.; Hays, R.D. Evaluation of the Patient-Reported Outcomes Information System (PROMIS ${ }^{\circledR}$ ) Spanish physical functioning items. Qual. Life Res. 2013, 22, 1819-1830. [CrossRef] [PubMed]

105. Community Business's Home Page Regarding China Achieving Gender Parity and Ranks Top among 6 Asian Markets. 2014. Available online: http://www.communitybusiness.org/library/News/2014/20141028_ GDBA2014_PressRelease_China.pdf (accessed on 7 December 2017).

106. International Monetary Fund's Home Page Regarding World Economic Outlook Database. 2017. Available online: http://www.imf.org/external/pubs/ft/weo/2017/01/weodata/weorept.aspx?sy=2015\&ey= 2022\&scsm $=1 \& s s d=1 \&$ sort $=$ country $\& d s=. \& b r=1 \& c=924 \& s=N G D P D \% 2 C N G D P D P C \% 2 C P P P G D P \%$ 2CPPPPC\&grp=0\&a=\&pr.x=75\&pr.y=16 (accessed on 7 December 2017). 
107. China Human Capital Report's Home Page. 2016. Available online: http://humancapital.cufe.edu.cn/en/ Human_Capital_Index_Project/Project_2016/China_Human_Capital_Report.htm (accessed on 7 December 2017).

108. Caci, H.; Nadalet, L.; Staccini, P.; Myquel, M.; Boyer, P. Psychometric properties of the French version of the Composite Scale of Morningness in adults. Eur. Psychiatry 1999, 14, 284-290. [CrossRef]

109. Adan, A.; Caci, H.; Prat, G. Reliability of the Spanish version of the Composite Scale of Morningness. Eur. Psychiatry 2005, 20, 503-509. [CrossRef] [PubMed]

110. Randler, C. Psychometric properties of the German version of the Composite Scale of Morningness. Biol. Rhythm. Res. 2008, 39, 151-161. [CrossRef]

111. Pornpitakpan, C. Psychometric properties of the composite scale of morningness: A shortened version. Personal. Individ. Differ. 1998, 25, 699-709. [CrossRef]

112. Gau, S.F.; Soong, W.T.; Lee, W.Y.; Chiu, Y.N. Reliability and validity of the Chinese version of the morningness/eveningness scale. Taiwan J. Psychiatry 1998, 12, 98-109.

113. Li, S.X.; Wang, X.F.; Liu, L.J.; Liu, Y.; Zhang, L.X.; Zhang, B.; Lu, L. Preliminary test for the Chinese version of the Morningness-Eveningness Questionnaire. Sleep Biol. Rhythm. 2011, 9, 19-23. [CrossRef]

114. Cronbach, L.J. Coefficient alpha and the internal structure of tests. Psychometrika 1951, 16, 297-334. [CrossRef]

115. Hinton, P.R.; Brownlow, C.; McMurray, I.; Cozens, B. SPSS Explained, 2nd ed.; Routledge Inc.: East Sussex, UK, 2014.

116. Likert, R.A. A technique for the measurement of attitudes. Arch. Psychol. 1932, 140, 5-55.

117. Lau, E.Y.Y.; Hui, C.H.; Lam, J.; Cheung, S.F. Sleep and optimism: A longitudinal study of bidirectional causal relationship and its mediating and moderating variables in a Chinese student sample. Chronobiol. Int. 2017, 34, 360-372. [CrossRef] [PubMed]

118. Wong, M.L.; Zhang, J.; Wing, Y.K.; Lau, E.Y.Y. Sleep-related daytime consequences mediated the neuroticism-depression link. Sleep Biol. Rhythm. 2017, 15, 21-30. [CrossRef]

119. Wong, M.L.; Lau, E.; Wan, J. The relationship between sleep quality and daytime sleepiness with chronotype latent constructs: An exploratory and confirmatory factor analysis in Chinese college students. Sleep 2012, $35,191$.

120. Bi, Y.X. On the death penalty for drug-related crime in China. Hum. Rights Drugs 2012, 2, $29-44$.

121. Holt, C.A.; Laury, S.H. Risk Aversion and Incentive Effects. Am. Econ. Rev. 2002, 92, 1644-1655. [CrossRef]

122. Eckel, C.C.; Grossman, P.J. Men, Women and Risk Aversion: Experimental Evidence. In Handbook of Experimental Economics Results; Plott, C., Smith, V., Eds.; Elsevier: New York, NY, USA, 2008; Volume 1, pp. 1061-1073.

123. Mandell, L.; Klein, L.S. The impact of financial literacy education on subsequent financial behaviour. Financ. Couns. Plan. 2009, 20, 15-24.

124. Fernandes, D.; Lynch, J.G., Jr.; Netemeyer, R.G. Financial literacy, financial education, and downstream financial behaviors. Manag. Sci. 2014, 60, 1861-1883. [CrossRef]

125. Lawrance, E.C. Poverty and the rate of time preference: Evidence from panel data. J. Political Econ. 1991, 99, 54-77. [CrossRef]

126. Rosen, A.B.; Tsai, J.S.; Downs, S.M. Variations in risk attitude across race, gender, and education. Med. Decis. Mak. 2003, 23, 511-517. [CrossRef] [PubMed]

127. Borghans, L.; Golsteyn, B.; Heckman, J.; Meijers, H. Gender differences in risk aversion and ambiguity aversion. J. Eur. Econ. Assoc. 2009, 7, 649-658. [CrossRef]

128. Bucciol, A.; Miniaci, R. Household portfolios and implicit risk preference. Rev. Econ. Stat. 2011, 93, $1235-1250$. [CrossRef]

129. Dittrich, M.; Leipold, K. Gender differences in time preferences. Econ. Lett. 2014, 122, 413-415. [CrossRef]

130. Neter, J.; Kutner, M.H.; Nachtsheim, C.J.; Wasserman, W. Applied Linear Statistical Models, 4th ed.; McGraw-Hill: Boston, MA, USA, 2004; Volume 4, p. 318.

131. Hayes, A.F. Introduction to Mediation, Moderation, and Conditional Process Analysis: A Regression-Based Approach; Guilford Press: New York, NY, USA, 2013.

132. Preacher, K.J.; Hayes, A.F. Asymptotic and resampling strategies for assessing and comparing indirect effects in multiple mediator models. Behav. Res. Methods 2008, 40, 879-891. [CrossRef] [PubMed]

133. Aiken, L.S.; West, S.G.; Reno, R.R. Multiple Regression: Testing and Interpreting Interactions; Sage: London, UK, 1999.

134. Hayes, A.F. An index and test of linear moderated mediation. Multivar. Behav. Res. 2015, 50, 1-22. [CrossRef] [PubMed] 
135. Chelminski, I.; Ferraro, F.R.; Petros, T.; Plaud, J.J. Horne and Ostberg questionnaire: A score distribution in a large sample of young adults. Personal. Individ. Differ. 1997, 23, 647-652. [CrossRef]

136. Andreoni, J.; Sprenger, C. Risk preferences are not time preference. Am. Econ. Rev. 2012, 102, 3357-3376. [CrossRef]

137. Killgore, W.D. Effects of sleep deprivation and morningness-eveningness traits on risk-taking. Psychol. Rep. 2007, 100, 613-626. [CrossRef] [PubMed]

138. Maestripieri, D. Night owl women are similar to men in their relationship orientation, risk-taking propensities, and cortisol levels: Implications for the adaptive significance and evolution of eveningness. Evol. Psychol. 2014, 12, 130-147. [CrossRef] [PubMed]

139. Gathergood, J. Self-control, financial literacy and consumer over-indebtedness. J. Econ. Psychol. 2012, 33, 590-602. [CrossRef]

140. Randler, C.; Saliger, L. Relationship between morningness-eveningness and temperament and character dimensions in adolescents. Personal. Individ. Differ. 2011, 50, 148-152. [CrossRef]

141. Randler, C. Morningness-eveningness, sleep-wake variables and big five personality factors. Personal. Individ. Differ. 2008, 45, 191-196. [CrossRef]

142. Cinan, S.; Doğan, A. Working memory, mental prospection, time orientation, and cognitive insight. J. Individ. Differ. 2013, 34, 159-169. [CrossRef]

143. Nowack, K.; van der Meer, E. Are larks future-oriented and owls present-oriented? Age-and sex-related shifts in chronotype-time perspective associations. Chronobiol. Int. 2013, 30, 1240-1250. [CrossRef] [PubMed]

144. Fleig, D.; Randler, C. Association between chronotype and diet in adolescents based on food logs. Eat. Behav. 2009, 10, 115-118. [CrossRef] [PubMed]

145. Nakade, M.; Takeuchi, H.; Kurotani, M.; Harada, T. Effects of meal habits and alcohol/cigarette consumption on morningness-eveningness preference and sleep habits by Japanese female students aged 18-29. J. Physiol. Anthropol. 2009, 28, 83-90. [CrossRef] [PubMed]

146. Goldstein, D.; Hahn, C.S.; Hasher, L.; Wiprzycka, U.J.; Zelazo, P.D. Time of day, intellectual performance, and behavioral problems in Morning versus Evening type adolescents: Is there a synchrony effect? Personal. Individ. Differ. 2007, 42, 431-440. [CrossRef] [PubMed]

147. Wittmann, M.; Paulus, M.; Roenneberg, T. Decreased psychological well-being in late 'chronotypes' is mediated by smoking and alcohol consumption. Subst. Use Misuse 2010, 45, 15-30. [CrossRef] [PubMed]

148. Susman, E.J.; Dockray, S.; Schiefelbein, V.L.; Herwehe, S.; Heaton, J.A.; Dorn, L.D. Morningness/eveningness, morning-to-afternoon cortisol ratio, and antisocial behavior problems during puberty. Dev. Psychol. 2007, 43, 811-822. [CrossRef] [PubMed]

149. Laibson, D. Golden eggs and hyperbolic discounting. Q. J. Econ. 1997, 112, 443-478. [CrossRef]

150. Fehr, E. Behavioural science: The economics of impatience. Nature 2002, 415, 269-272. [CrossRef] [PubMed]

151. Heidhues, P.; Koszegi, B. Exploiting naivete about self-control in the credit market. Am. Econ. Rev. 2010, 100, 2279-2303. [CrossRef]

152. Hur, Y.M. Stability of genetic influence on morningnesseveningness: A cross-sectional examination of South Korean twins from preadolescence to young adulthood. J. Sleep Res. 2007, 16, 17-23. [CrossRef] [PubMed]

153. Buschkens, J.; Graham, D.; Cottrell, D. Well-being under chronic stress: Is morningness an advantage? Stress Health 2010, 26, 330-340. [CrossRef]

154. Roeser, K.; Obergfell, F.; Meule, A.; Vögele, C.; Schlarb, A.A.; Kübler, A. Of larks and hearts-Morningness/eveningness, heart rate variability and cardiovascular stress response at different times of day. Physiol. Behav. 2012, 106, 151-157. [CrossRef] [PubMed]

155. Kandasamy, N.; Hardy, B.; Page, L.; Schaffner, M.; Graggaber, J.; Powlson, A.S.; Coates, J. Cortisol shifts financial risk preferences. Proc. Natl. Acad. Sci. USA 2014, 111, 3608-3613. [CrossRef] [PubMed]

156. Dallman, M.F.; Bhatnagar, S. Chronic Stress and Energy Balance: Role of the Hypothalamo-Pituitary-Adrenal Axis. In Handbook of Physiology, Section 7. The Endocrine System; McEwen, B., Ed.; Oxford University Press: New York, NY, USA, 2010; pp. 179-210.

157. Lupien, S.J.; Wilkinson, C.W.; Brière, S.; Ménard, C.; Kin, N.N.Y.; Nair, N.P.V. The modulatory effects of corticosteroids on cognition: Studies in young human populations. Psychoneuroendocrinology 2002, 27, 401-416. [CrossRef] 
158. Cueva, C.; Roberts, R.E.; Spencer, T.; Rani, N.; Tempest, M.; Tobler, P.N.; Rustichini, A. Cortisol and testosterone increase financial risk taking and may destabilize markets. Sci. Rep. 2015, 5, 1-16. [CrossRef] [PubMed]

159. Bailey, S.L.; Heitkemper, M.M. Morningness-eveningness and early-morning salivary cortisol levels. Biol. Psychol. 1991, 32, 181-192. [CrossRef]

160. Kudielka, B.M.; Federenko, I.S.; Hellhammer, D.H.; Wüst, S. Morningness and eveningness: The free cortisol rise after awakening in "early birds" and "night owls". Biol. Psychol. 2006, 72, 141-146. [CrossRef] [PubMed]

161. Griefahn, B.; Robens, S. The cortisol awakening response: A pilot study on the effects of shift work, morningness and sleep duration. Psychoneuroendocrinology 2008, 33, 981-988. [CrossRef] [PubMed]

162. Randle, C.; Schaal, S. Morningness-eveningness, habitual sleep-wake variables and cortisol level. Biol. Psychol. 2010, 85, 14-18. [CrossRef] [PubMed]

163. Randler, C.; Ebenhöh, N.; Fischer, A.; Höchel, S.; Schroff, C.; Stoll, J.C.; Vollmer, C. Chronotype but not sleep length is related to salivary testosterone in young adult men. Psychoneuroendocrinology 2012, 37, 1740-1744. [CrossRef] [PubMed]

164. Grable, J.E.; Roszkowski, M.J. The influence of mood on the willingness to take financial risks. J. Risk Res. 2008, 11, 905-923. [CrossRef]

165. Kuhnen, C.M.; Knutson, B. The influence of affect on beliefs, preferences, and financial decisions. J. Financ. Quant. Anal. 2011, 46, 605-626. [CrossRef]

166. Barsky, R.B.; Juster, F.T.; Kimball, M.S.; Shapiro, M.D. Preference parameters and behavioral heterogeneity: An experimental approach in the health and retirement study. Q. J. Econ. 1997, 112, 537-579. [CrossRef]

167. Charness, G.; Gneezy, U.; Imas, A. Experimental methods: Eliciting risk preferences. J. Econ. Behav. Organ. 2013, 87, 43-51. [CrossRef]

168. Gafni, A.; Torrance, G.W. Risk attitude and time preference in health. Manag. Sci. 1984, 30, 440-451. [CrossRef]

169. Kahneman, D.; Tversky, A. Prospect theory: An analysis of decision under risk. Econ. J. Econ. Soc. 1979, 47, 263-291.

170. Zimbardo, P.G.; Boyd, J.N. Putting time in perspective: A valid, reliable individual-differences metric. J. Pers. Soc. Psychol. 1999, 77, 1271-1288. [CrossRef]

171. Levin, K.A. Study design III: Cross-sectional studies. Evid.-Based Dent. 2006, 7, 24-25. [CrossRef] [PubMed]

172. Carciofo, R.; Du, F.; Song, N.; Qi, Y.; Zhang, K. Age-related chronotype differences in Chinese, and reliability assessment of a reduced version of the Chinese Morningness-Eveningness Questionnaire. Sleep Biol. Rhythm. 2012, 10, 310-318. [CrossRef]

173. Kerkhof, G.A. Inter-individual differences in the human circadian system: A review. Biol. Psychol. 1985, 20, 83-112. [CrossRef]

174. Caci, H.; Adan, A.; Bohle, P.; Natale, V.; Pornpitakpan, C.; Tilley, A. Transcultural properties of the composite scale of morningness: The relevance of the "morning affect" factor. Chronobiol. Int. 2005, 22, 523-540. [CrossRef] [PubMed]

(C) 2018 by the authors. Licensee MDPI, Basel, Switzerland. This article is an open access article distributed under the terms and conditions of the Creative Commons Attribution (CC BY) license (http://creativecommons.org/licenses/by/4.0/). 